\title{
Antitrust and State Action: Economic Efficiency and the Political Process*
}

\author{
Merrick B. Garland $†$
}

The analysis of legal doctrine in terms of its contribution to economic efficiency originated in antitrust law. ${ }^{1}$ Since then, a succession of scholars has extended this form of analysis across the legal board, from tort law to corporate law, from crimes to the Constitution. ${ }^{2}$ Now, a rising chorus is urging that the enterprise be brought full circle: In effect, these authors argue not only that economic efficiency criteria should govern antitrust, but that antitrust in turn should govern all other legislation-at least in the nonfederal sphere.

The vehicle for accomplishing this result is a revision of antitrust's state action doctrine. That doctrine currently immunizes the regulatory policies of states from attack under the Sherman Act. According to the revisionists, the courts should substantially narrow the scope of state action immunity to permit the preemption of a greater number of economically inefficient state regulations. ${ }^{3}$

* 1986 Merrick B. Garland

$\dagger$ Harvard University, A.B. 1974; J.D. 1977. Mr. Garland is a partner in the Washington, D.C. law firm of Arnold \& Porter and was a Lecturer on Law at Harvard Law School during 1985-86. He would like to thank Phillip Areeda and Robert Pitofsky for their helpful comments on an earlier draft.

1. See, e.g., Bork, Vertical Integration and the Sherman Act: The Legal History of an Economic Misconception, 22 U. CHI. L. REv. 157 (1954); Director \& Levi, Law and the Future: Trade Regulation, 51 Nw. U.L. Rev. 281 (1956).

2. See, e.g., G. Calabresi, The Costs of Accidents (1970); Easterbrook, Foreword: The Court and the Economic System, 98 HARv. L. REv. 4 (1984) [hereinafter Easterbrook, Foreword]; Manne, Our Two Corporation Systems: Law and Economics, 53 VA. L. Rev. 259 (1967); Essays IN The Economics of Crime and Punishment (G. Becker \& W. Landes eds. 1974). See generally R. Posner, ECONOMic ANalysis of Law (3d ed. 1986).

3. The term "revisionists" is used here as a general label for advocates of a wide variety of proposals to revise the state action doctrine. Their views are described in such recent works as Cirace, $A n$ Economic Analysis of the "State-Municipal Action" Antitrust Cases, 61 TEx. L. REv. 481, 484, 486, 498, 514-15 (1982); Easterbrook, Foreword, supra note 2, at 51-54; Werden \& Balmer, Conflicts Between State Law and the Sherman Act, 44 U. PITr. L. REv. 1, $58-72$ (1982); and Wiley, A Capture Theory of Antitrust Federalism, 99 HARv. L. Rev. 713 (1986). For earlier versions of the revisionist approach, see Cantor v. Detroit Edison Co., 428 U.S. 579, 610-13 (1976) (Blackmun, J., concurring); Donnem, Federal Antitrust Law Versus Anticompetitive State Regulation, 39 ANTITRUST L.J. 950 (1970); Kennedy, Of Lawyers, Lightbulbs and Raisins: An Analysis of the State Action Doctrine Under the Antitrust Laws, 74 Nw. U.L. Rev. 31, 32-33, $72-75$ (1979); Posner, The Proper Relationship Between State Regulation and the Federal Antitrust Laws, 49 N.Y.U. L. REv. 693, 707, 714 (1974); Slater, Antitrust and Government Action: A Formula for Narrowing Parker v. Brown, 69 Nw. U.L. Rev. 71, 74, 105, 109 (1974).

Although Judge Easterbrook shares elements of the revisionist position, particularly its description of the assumptions that underlie the Court's current approach to state action, his prescription for 
The revisionist analysis has both descriptive and prescriptive elements. Some scholars argue that the Supreme Court's state action cases already evidence an underlying trend toward greater judicial intrusion into state regulatory policies-a trend which reflects an increasing skepticism toward the economic value of regulation and, more specifically, an increasing suspicion that regulation serves only the special interests of those who lobby for it. ${ }^{4}$ In addition, many find such a trend praiseworthy, suggesting only that judicial intervention be enhanced so as to ensure economic efficiency even more efficiently. ${ }^{5}$ An improved state action doctrine, they contend, will better accomplish what is assertedly its only legitimate function: permitting the preemption of state regulation imposing an unwarranted restraint on market competition. ${ }^{6}$

This Article argues that the revisionist analysis is wrong on both its descriptive and prescriptive levels. First, the state action cases do not exhibit an inexorable trend toward greater federal intrusion, and have little to do either with notions of economic efficiency or with suspicions that regulatory programs have been captured by special interests. To the contrary, the cases, including the most recent ones involving "municipal" action, reflect an increasing deference toward state regulation. This deference represents the judiciary's effort to respect the results of the political process, tempered only by the compromises needed to accommodate respect for that process at both the state and federal levels. As discussed below, the Supreme Court has sought such an accommodation by applying the state action doctrine to oust those state regulations-but only those state regulations-that seek to delegate to private parties the power to restrain market competition.

Second, this Article argues that the Court's effort is fundamentally correct. The judiciary should not interfere under the aegis of the antitrust

change would limit the preemption of inefficient state regulations to those which export overcharges beyond the bounds of the regulating state. See Easterbrook, Foreword, supra note 2, at 51 n.120; Easterbrook, Antitrust and the Economics of Federalism, 26 J.L. \& Econ. 23, 27-28, 45-50 (1983) [hereinafter Easterbrook, Antitrust and Federalism]. In addition, although as discussed in the text the practical effect of Professor Wiley's proposed revision of the state action doctrine is to narrow it substantially, there are circumstances under which his proposal theoretically could immunize state action not protected under current law. See infra note 181. Finally, it should be noted that others who have applied economic analysis to the state action doctrine have reached conclusions quite opposite those of the revisionists, arguing for greater rather than lesser deference to local regulation. See, e.g., Lopatka, State Action and Municipal Antitrust Immunity: An Economic Approach, 53 FordHam L. REv. 23, 25-26 (1984).

4. See Cirace, supra note 3, at 484, 486, 514-15; Easterbrook, Foreword, supra note 2, at 51-54; Easterbrook, Antitrust and Federalism, supra note 3, at 27; Wiley, supra note 3, at 714-15, 718-19, 723-27, 789.

5. See Cirace, supra note 3, at 486, 498, 514-15; Werden \& Balmer, supra note 3, at 58-72; Wiley, supra note 3 , at 743-44, 748-56, 772-73; see also Cantor, 428 U.S. at 610-11 (Blackmun, J., concurring); Donnem, supra note 3, at 966-67; Kennedy, supra note 3, at 73; Posner, supra note 3, at 707, 714; Slater, supra note 3, at 74, 105, 109.

6. See Wiley, supra note 3 , at 788 . 
laws with a state's political decision, however misguided it may be, to substitute regulation for the operation of the market. Despite protestations, the revisionist proposal is little more than a return to the era the Court left behind when it repudiated Lockner $v$. New York. ${ }^{7}$ The substitution of "antitrust" for "due process" and "economic efficiency" for "liberty of contract" does not make the assault on democratic politics any more palatable.

\section{The Court's Current Approach to State Action}

State action immunity was born in the 1943 case of Parker $v$. Brown, ${ }^{8}$ in which the Supreme Court held that Congress had not intended the Sherman Act to bar states from imposing restraints on competition. The Court largely ${ }^{9}$ ignored the issue for the next thirty years until, in the mid1970 's, it began struggling over the appropriate test for determining whether a restraint in fact constitutes "state action." Various opinions suggested that Parker immunity did not apply unless (1) private parties acting under the restraint had been compelled to do so by the state; ${ }^{10}(2)$ the state itself had been named as a defendant; ${ }^{11}$ or $^{12}$ (3) immunity was "necessary" in order to make the state's regulatory program work. ${ }^{13}$ By the time of its 1980 opinion in California Retail Liquor Dealers Association v. Midcal Aluminum, Inc. ${ }^{14}$ however, a unanimous Gourt had settled upon a different, two-pronged test for state action immunity: To receive immunity, the challenged restraint had to be (1) "clearly articulated and affirmatively expressed as state policy," and (2) "actively supervised" by the state itself. ${ }^{15}$ With certain exceptions for restraints imposed by mu-

7. 198 U.S. 45 (1905). In Lochner and subsequent cases, state economic regulation was overturned under the due process clause of the Fourteenth Amendment. The Court repudiated this "substantive due process" approach in Nebbia v. New York, 291 U.S. 502 (1934), and West Coast Hotel v. Parrish, 300 U.S. 379 (1937). See infra text accompanying notes 142-49.

8. 317 U.S. 341 (1943). Parker upheld the validity of a California program regulating the marketing of the state's raisin crop.

9. But see Schwegmann Bros. v. Calvert Distillers Corp., 341 U.S. 384 (1951) (discussed infra text accompanying notes 122-25).

10. See Bates v. State Bar, 433 U.S. 350, 359-60 (1977); Cantor v. Detroit Edison Co., 428 U.S. 579, 592-94 \& n.28 (1976); Goldfarb v. Virginia State Bar, 421 U.S. 773, 791 (1975).

11. See Bates, 433 U.S. at 361; Cantor, 428 U.S. at 591-92, 601 (opinion of Stevens, J.).

12. The Court's opinions did not make clear the degree to which the various tests had independent significance.

13. See Bates, 433 U.S. at 361; Cantor, 428 U.S. at 597-98. Individual Justices suggested further requirements, including (1) that the restraint not involve a municipality's "proprietary" enterprises, see City of Lafayette v. Louisiana Power \& Light Co., 435 U.S. 389, 418 (1978) (Burger, C.J., concurring); and (2) that the restraint satisfy a "rule of reason" under which its benefits outweigh its potential harms, see Cantor, 428 U.S. at 610-11 (Blackmun, J., concurring).

14. 445 U.S. 97 (1980).

15. See Midcal, 445 U.S. at 105. This test was anticipated in 1 P. AreEdA \& D. Turner, ANTutrust LAw I 212c (1978), and in several earlier opinions. See New Motor Vehicle Bd. v. Orrin W. Fox Co., 439 U.S. 96, 109-10 (1978); City of Lafayeite, 435 U.S. at 410 (opinion of Brennan, J.); 
nicipalities, ${ }^{16}$ the two-pronged Midcal test continued to hold sway through the 1984-85 Term. $^{17}$ Although the Court's recent opinion in Fisher $v$. City of Berkeley ${ }^{18}$ once again casts matters into doubt, one can, as discussed below, read the new test propounded in Fisher as merely restating Midcal's basic tenets. ${ }^{19}$

Numerous other commentators have traced the development of the state action doctrine and have described its workings in detail. ${ }^{20}$ The question considered here is what Parker's progeny reflect about the Court's views on the appropriate relation between the federal judiciary and state regulation. This Part considers two quite different conclusions regarding that question.

\section{A. State Action Immunity as Skepticism About Capture}

\section{The Theory}

According to the revisionists, Parker $v$. Brown represents a naive, nowdiscredited confidence in the value of regulation. A child of the New Deal, Parker assertedly saw regulation both as an economically necessary effort to correct market defects, and as a politically legitimate effort to serve the public interest. It was this public interest vision that drove the Court to defer to state regulation and declare it off-limits to antitrust challenge. ${ }^{21}$

Since those days, the revisionists argue, that public interest conception has eroded deeply. ${ }^{22}$ An increasing economic sophistication has unmasked the inefficiency of regulation and its failure to correlate with, much less correct, market failure. Perhaps more important, this shift in the intellectual environment has brought increased suspicion that regulation serves not the public interest, but rather the private interests of groups that either have "captured" regulatory bodies, or have controlled them from the start through their successful efforts to lobby the legislature. Regulation is

Bates, 433 U.S. at 362.

16. See infra text accompanying notes 48-63, 89-96.

17. See Southern Motor Carriers Rate Conf. v. United States, 471 U.S. 48, 57 (1985); Town of Hallie v. City of Eau Claire, 471 U.S. 34, 39-40 (1985); Hoover v. Ronwin, 466 U.S. 558, 569 (1984); Community Communications Co. v. City of Boulder, 455 U.S. 40, 51 \& n.14 (1982).

18. 106 S. Ct. 1045 (1986).

19. See infra text accompanying notes 64-71, 97-135.

20. See, e.g., 1 P. AREenA \& D. TuRner, supra note 15, gl 207-17; Jorde, Antitrust and the New "State Action" Doctrine: A Return to Deferential Economic Federalism, 75 CALIF. L. REv. (forthcoming); authorities cited supra note 3.

21. See Easterbrook, Foreword, supra note 2, at 52-53; Easterbrook, Antitrust and Federalism, supra note 3, at 27; Werden \& Balmer, supra note 3, at 69-70; Wiley, supra note 3, at 714-15, 718-19. See generally S. BREYER, Regulation and ITs ReForm 10 (1982) (describing public interest theory); Posner, Theories of Economic Regulation, 5 BELL. J. EcON. \& MGMT. SCI. 335, 336 (1974) (same).

22. See Easterbrook, Foreword, supra note 2, at 52-54; Easterbrook, Antitrust and Federalism, supra note 3, at 23-24; Wiley, supra note 3, at 714-15, 723-26. 
seen not as a bona fide effort to correct market defects, but as a conscious attempt to create such defects in order to favor politically adept special interests. ${ }^{23}$ There are numerous versions of this interest group theory, some crude and some sophisticated, some espoused by the Left and some by the Right, some formulated by economists and some by lawyers or political scientists. ${ }^{24}$ In his recent article, Professor John Wiley uses the shorthand "capture theory" to capture their essence. ${ }^{25}$

This interest group or capture theory has finally replaced the old New Deal model in the eyes of the Court, argue Professor Wiley, Judge Frank Easterbrook, and others. And it is this skepticism about the value of regulation, and this suspicion of regulation's true motives, that are now assertedly driving the post-Parker state action cases. ${ }^{23}$ Parker's deference toward state regulation purportedly has been replaced by an increasing willingness to subject state regulatory policies to federal antitrust scrutiny, a willingness which has led the Court to reject state action defenses in numerous cases since Parker v. Brown. Moreover, as deregulation continues to replace regulation on the national political agenda, we are told that we may expect these judicial intrusions into anticompetitive state programs to accelerate. ${ }^{27}$

\section{The Theory's Defects}

As an empirical description of the Supreme Court's state action cases, the capture theory could not be more wrong. To begin with, there is little if anything in the language of the opinions that suggests the Court was reacting to a capture conception of regulation. ${ }^{28}$ Indeed, in those few cases

23. See authorities cited supra note 22 .

24. See, e.g., R. Fellmeth, The Interstate Commerce, Omission: The Public Interest and THE ICC (1970); G. Kol.ko, The Triumph of Conservatism (1963); R. Posner, supra note 2, at 405-07; Green \& Nader, Economic Regulation vs. Competition: Uncle Sam the Monopoly Man, 82 YAle L.J. 871, 876 (1973); Peltzman, Toward a More General Theory of Regulation, 19 J.L. \& Econ. 211 (1976); Stigler, The Theory of Economic Regulation, 2 BeLl. J. Econ. \& MGMT. ScI. 3 (1971). See generally S. BREYER, supra note 21, at 9-10 (describing capture and interest group theories); Posner, supra note 21, at 341-43 (same); Stewart, The Reformation of American Administrative Law, 88 HaRv. L. REv. 1667, 1684-85, 1687 (1975) (same).

25. See Wiley, supra note 3 , at 723-28.

26. See Easterbrook, Foreword, supra note 2, at 18-19, 42, 51-54; Easterbrook, Antitrust and Federalism, supra note 3, at 27; Wiley, supra note 3 , at 714-15, 723, 727-28, 789; see also Town of Hallie v. City of Eau Claire, 700 F.2d 376, 379 n.3 (7th Cir. 1983) (Wisdom, J.), affd, 471 U.S. 34 (1985); H.R. ReP. No. 965, 98th Cong., 2d Sess. 6 n.4 (1984); M. HANDLER, Reforming the ANTITRUST LAws 59-60 (1982).

27. See Easterbrook, Foreword, supra note 2, at 18-19, 51-54; Wiley, supra note 3, at 714, 719-23, 726-28.

28. Accord Wiley, supra note 3 , at 723, 727-28. Professor Wiley concedes that the only language evincing a concern with capture is the citation by two Justices to law review articles that Wiley regards as "capture literature," in cases in which the Court nonetheless upheld state action defenses. See id. at 727 n.66 (noting Hoover v. Ronwin, 466 U.S. 558, 584 (1984) (Stevens, J., dissenting); Bates v. State Bar, 433 U.S. 350, 377 n.34 (1977)). Judge Easterbrook notes the same citations. See 
in which the Court did note that the challenged legislation had been lobbied for by private interests, it upheld rather than rejected the state action defense.

In New Motor Vehicle Board v. Orrin W. Fox Co. ${ }^{29}$ for example, the Court upheld perhaps the most "captured" scheme ever to come before it: a California regulation permitting established automobile dealers to delay substantially the establishment of competing franchises in their geographic markets. Despite Justice Stevens' dissenting view that the regulation represented nothing more than the success of the car dealers in lobbying the state legislature for a special anticompetitive benefit, ${ }^{30}$ the Court held that the state action exemption put the regulation beyond the reach of the antitrust laws. ${ }^{31}$ Just one Term before, and over a similar dissent, the Court had upheld a Maryland statute barring oil company ownership of service stations-despite ample evidence that the statute was the successful product of a lobbying campaign by retail gasoline dealers. ${ }^{\mathbf{3 2}}$

Lacking internal indicia that the Justices have been motivated by concern over anticompetitive capture, the revisionists must fall back on what they perceive as parallels in timing between increasing intellectual skepticism toward regulation and the Court's increasingly intrusive state action

Easterbrook, Foreword, supra note 2, at 16 n.16. Professor Wiley also points to judicial references to the "anticompetitive" nature of the restraints under attack in other cases. Such references are to be expected, however, because if restraints are not at least assumed to be anticompetitive, consideration of a state action defense would be both unnecessary and irrelevant.

29. 439 U.S. $96(1978)$.

30. See 439 U.S. at $115,120$.

31. 439 U.S. at 109.

32. Exxon Corp. v. Governor of Md., 437 U.S. 117, 129-34 (1978); see id. at 140 n.7, 141 \& n.8, 143 n.10 (Blackmun, J., concurring and dissenting in part); see also New Motor Vehicle Bd., 439 U.S. at 115 (Stevens, J., dissenting). Nor are these two the only illustrations of "captured" regulations nonetheless upheld by the Court. Both Professor Wiley and Judge Easterbrook, for example, regard Hoover v. Ronwin, 466 U.S. 558 (1984), which immunized Arizona lawyers' alleged use of state law to restrict competitive entry into the legal profession, as a case of interest group capture. See Wiley, supra note 3, at 739 n.131; Easterbrook, Foreword, supra note 2, at 53. The Court, however, held that permitting "Sherman Act plaintiffs to look behind the actions of state sovereigns and base their claims on perceived conspiracies to restrain trade among [those who] . . advise the sovereign ... would emasculate the Parker v. Brown doctrine." 466 U.S. at 580.

Of course, there are examples of cases involving what could be viewed as "captured" restraints where the Court has refused to validate state action defenses. See, e.g., Goldfarb v. Virginia State Bar, 421 U.S. 773 (1975) (overturning minimum-fee schedules enforced by state bar); Wiley, supra note 3, at 769 . But since almost any regulation subject to antitrust challenge can be characterized as serving one special interest or another, see infra text accompanying note 180 , such evidence is of little weight. Similarly, there certainly are examples of cases involving economically inefficient state regulations where the Court has declined to find state action. Had the Court been motivated solely by a distaste for economic inefficiency, however, virtually every state action defense to come before it would have been rejected-rather than just the handful that were. See, e.g., S. BREYER, supra note 21, at 225 (criticizing trucking regulation like that later upheld in Southern Motor Carriers Rate Conf. v. United States, 471 U.S. 48 (1985)); E. Mansfield, PRinciples of Microeconomics 73-74 (4th ed. 1983) (criticizing rent control ordinance like that at issue in Fisher v. City of Berkeley, $106 \mathrm{~S}$. Ct. 1045 (1986)); R. Rogers, The Effect of State Entry Regulation on Retail Automobile Markets (FTC Staff Report, Jan. 1986) (criticizing state regulation like that upheld in New Motor Vehicle Bd.). 
decisions. ${ }^{33}$ Such an approach might well be subject to attack as post hoc reasoning-except that the asserted trend simply is not there.

It is true that the Court rejected state action defenses in a number of post-Parker cases. ${ }^{34}$ It is also true that during the mid-1970's the Court toyed with a number of state action tests, such as the requirement that the restraint be compelled and not simply approved by the state, that would have significantly narrowed the doctrine and permitted substantial judicial intrusion into state regulatory policies. ${ }^{35}$ But despite the blossoming in the 1980's of a bipartisan, national consensus favoring economic deregulation, ${ }^{36}$ the recent trend in the state action cases has been one of greater judicial deference toward state regulatory policies. Since mid-1982, while deregulation has triumphed in Congress, ${ }^{37}$ the Court has upheld against antitrust attack all five state or local regulatory schemes that have come before it. $^{38}$ Indeed, in the Terms following Judge Easterbrook's pronouncement that the Justices had finally gotten the hang of economic

33. See Wiley, supra note 3 , at 728 .

34. The Court rejected a state action defense in six cases decided after Parker. See Community Communications Co. v. City of Boulder, 455 U.S. 40 (1982); California Retail Liquor Dealers Ass'n v. Midcal Aluminum, Inc., 445 U.S. 97 (1980); City of Lafayette v. Louisiana Power \& Light Co., 435 U.S. 389 (1978); Cantor v. Detroit Edison Co., 428 U.S. 579 (1976); Goldfarb v. Virginia State Bar, 421 U.S. 773 (1975); Schwegmann Bros. v. Calvert Distillers Corp., 341 U.S. 384 (1951). Professor Wiley finds two additional rejections by counting Maryland v. United States, 460 U.S. 1001 (1983), which affirmed without Court opinion Judge Green's hundred-page opinion in the AT\&T divestiture case, of which only two pages dealt with state action, see United States v. AT\&T, 552 F. Supp. 131, 157-58 (D.D.C. 1982); and by counting Flood v. Kuhn, 407 U.S. 258, 284 (1974), which held that professional baseball was exempt from federal antitrust law and that the commerce clause precluded the application of state antitrust laws, all without any mention of Parker $v$. Brown. See Wiley, supra note 3, at 719-22.

On the other hand, depending upon how one counts, the Court has upheld state action from antitrust attack in equal or greater numbers. See Fisher v. City of Berkeley, 106 S. Ct. 1045 (1986); Southern Motor Carriers Rate Conf. v. United States, 471 U.S. 48 (1985); Town of Hallie v. City of Eau Claire, 471 U.S. 34 (1985); Hoover v. Ronwin, 466 U.S. 558 (1984); New Motor Vehicle Bd. v. Orrin W. Fox Co., 439 U.S. 96 (1978); Bates v. State Bar, 433 U.S. 350 (1977); see also Rice v. Norman Williams Co., 458 U.S. 654 (1982) (preemption analysis); Exxon Corp. v. Governor of Míd., 437 U.S. 117 (1978) (same); Seagram \& Sons v. Hostetter, 384 U.S. 35 (1966) (same).

In its most recent opinion, FTC v. Indiana Federation of Dentists, 106 S. Ct. 2009 (1986), the Court upheld the FTC's determination that the Federation violated $\S 5$ of the Federal Trade Commission Act by forbidding its members to submit $x$-rays to dental insurers for use in claim determinations. In so doing, the Court rejected the Federation's assertion that its action was "immunized from antitrust scrutiny by virtue of a supposed policy of the State of Indiana against the evaluation of dental $x$ rays by lay employees of insurance companies." Id. at 2021. The Court noted the FTC's finding that there was no such state policy, and further noted that even if there were, there was no suggestion that the state had supervised the Federation's boycott as a method of enforcing such a policy. Id.

35. See supra note 13 and text accompanying notes 10-13 (describing five such tests).

36. See Garland, Deregulation and Judicial Review, 98 HARv. L. REv. 507, 507-08 (1985).

37. See id. at 508 .

38. See Fisher v. City of Berkeley, 106 S. Ct. 1045 (1986); Southern Motor Carriers Rate Conf. v. United States, 471 U.S. 48 (1985); Town of Hallie v. City of Eau Claire, 471 U.S. 34 (1985); Hoover v. Ronwin, 466 U.S. 558 (1984); Rice v. Norman Williams Co., 458 U.S. 654 (1982). FTC v. Indiana Federation of Dentists, 106 S. Ct. 2009 (1986), did not involve a challenge to a state's regulatory policy. See supra note 34 . 
analysis, ${ }^{39}$ the Court issued its three most deferential opinions and rejected the earlier, more intrusive state action tests.

\section{a. The Southern Motor Carriers Case}

The first of these cases, Southern Motor Carriers Rate Conference v. United States, ${ }^{40}$ involved a challenge by the Justice Department to the trucking regulations of four states. The state regulations permitted competitors, operating through "rate bureaus," to agree upon rates for submission to state public service commissions. Notwithstanding widespread scholarly opinion that trucking regulation constitutes a classic form of industry capture and inefficient regulation, ${ }^{41}$ the Court found the regulations immune from antitrust scrutiny. In so holding, the Court rejected state action tests suggested in earlier opinions that would have limited the defense to cases where the state compelled the anticompetitive activity, the state itself was the defendant, or immunity was necessary to make the regulatory program work. ${ }^{42}$ The two-pronged Midcal test, Justice Powell confirmed, alone determined the presence of immunity. ${ }^{43}$ As long as the regulation represented clearly articulated state policy, and as long as the state supervised any private anticompetitive conduct, the regulation would be free from antitrust review.

Equally important, Southern Motor Carriers may well represent a softening of the Midcal test itself. ${ }^{44}$ The Court had previously insisted that approval by a state agency did not alone constitute sufficient state authorization to immunize private anticompetitive conduct. ${ }^{45}$ Yet, although three of the states involved in the Southern Motor Carriers case had statutes expressly permitting truckers to agree on the rates they submitted to the states' utility commissions, the Mississippi defense relied on a statute which simply gave that state's commission the authority to regulate rates, buttressed by a commission rule permitting collective ratemak-

39. See Easterbrook, Foreword, supra note 2, at 4-5, 51, 59.

40. 471 U.S. 48 (1985).

41. See, e.g., S. BrEYer, supra note 21, at 222-39; R. Fellmeth, supra note 24; Moore, Deregulating Surface Freight Transportation, in Promoting CoMPetition IN Regulated MaRKETS 55-98 ( $\Lambda$. Phillips ed. 1975); Stigler, supra note 24, at 5-6. Professor Wiley agrees with this characterization of the state schemes. Wiley, supra note 3 , at 739 n.131, 754-56.

42. See 471 U.S. at 56, 57 n.21, 60-61 (rejecting suggested interpretations of Cantor and Goldfarb cases); see also supra notes $10-13$ and accompanying text.

43. See 471 U.S. at 57,61 .

44. Although Professor Wiley acknowledges that Southern Motor Carriers-as well as Town of Hallie v. City of Eau Claire, 471 U.S. 34 (1985)-may reflect some liberalization of the "clear articulation" requirement, he regards them as offering "but slight relief to states." See Wiley, supra note 3, at $737-39 \& 739$ n. 130 .

45. See, e.g., Cantor v. Detroit Edison Co., 428 U.S. 579, 585 (1976). Although the Court reiterated this point in Southern Motor Carriers, 471 U.S. at 62-63, the actual outcome of the case-as noted in the text-suggests a weakening of the Court's earlier position. 
ing. As the Court noted, this raised the question whether the absence of a statutory provision meant that Mississippi did not have a "clearly articulated" state policy. Nevertheless, the Court found Midcal's first prong ${ }^{46}$ satisfied by the legislature's determination that the commission rather than the market should set trucking rates. As long as the state has determined to displace competition with a regulatory regime, the Court held, a private defendant "need not 'point to a specific, detailed legislative authorization' for its challenged conduct."

\section{b. The Municipal Action Cases}

The Court's retreat from federal intrusion is nowhere as apparent as in its two recent cases involving restraints imposed by municipalities rather than states. In two earlier cases, City of Lafayette v. Louisiana Power $\mathbb{E}$ Light Co. ${ }^{48}$ and Community Communications Co. v. City of Boulder, ${ }^{49}$ the Court had set the stage for a potentially sweeping invalidation of local government regulations by holding that cities were not entitled to the same antitrust immunity as states; like private defendants, cities would have to satisfy at least the first prong of $\mathrm{Midcal}^{50}$ - proof that a clearly articulated state policy sanctioned the restraint in question. ${ }^{51}$ In Boulder, the Court held that general "home rule" powers granted the city by the state constitution $^{\text {52 }}$ were insufficient to immunize from antitrust challenge Boulder's regulation of cable television: "A State that allows its municipalities to do

46. The second, "supervision" prong was not at issue in Southern Motor Carriers because the government had conceded it was satisfied. See 471 U.S. at $62,66$.

47. Id. at 64 (quoting City of Lafayette v. Louisiana Power \& Light Co., 435 U.S. 389, 415 (1978) (opinion of Brennan, J.)).

48. 435 U.S. 389 (1978).

49. 455 U.S. 40 (1982).

50. The Court in Lafayette suggested, although it did not decide, that a municipality would also have to satisfy Midcal's second prong-proof that the state actively supervised the restraint. See 435 U.S. at 410 (plurality opinion). In Boulder, the Court expressly declined to reach that question. See 455 U.S. at 51-52 n.14.

51. Boulder, 455 U.S. at 52; Lafayette, 435 U.S. at 413 (plurality opinion).

It is worth noting that the Court rejected immunity in these cases despite the absence of even a whiff of capture in either of them, a point Professor Wiley concedes for Lafayette but disputes for Boulder. See Wiley, supra note 3, at 766-67, 769. But if any of the players in Boulder could be said to have "captured" the city council, it would have to be the plaintiff, the holder of the city's sole cable permit who, ironically, sought to use the antitrust laws to attack the city's efforts to induce new entrants into the market. There was no evidence that the private party defendant, one of those potential entrants, had "captured" the city council; all it had done was write the council requesting a permit to provide competing service, see 455 U.S. at $44-45$, surely an act protected by the First Amendment, see infra text accompanying notes 161-81; see also 455 U.S. at 47 n.9 (noting trial court finding that evidence was insufficient to establish conspiracy between city and defendant permit seeker).

52. See Colo. Const. art. XX, $\$ 6$ ("It is the intention of this article to grant and confirm to the people of all municipalities coming within its provisions the full right of self-government in both local and municipal matters."). 
as they please can hardly be said to have 'contemplated' the specific anticompetitive actions for which municipal liability is sought."

The Boulder decision was met by a flurry of political and academic criticism stressing its threat to municipal policymaking. ${ }^{54}$ Congress swiftly passed a bill effectively reversing the case as far as treble damage actions were concerned. ${ }^{\mathrm{b}}$ And in its next municipal action opinion, Town of $\mathrm{Hal}$ lie v. City of Eau Claire, ${ }^{58}$ the Court made clear that it had gotten the message.

Under attack in Hallie was the City of Eau Claire's insistence that unannexed neighboring towns use its sewage collection and transportation services if they wished to use its sewage treatment facility, the only one in the area. Although the Court began by proclaiming its allegiance to Boulder, it in fact drew back considerably. First, the Court addressed an issue it had left open in Boulder: whether the second prong of the Midcal test, the requirement of active supervision by the state, applied to municipal defendants. The Court held that it did not. "Where the actor is a municipality," Justice Powell said, "there is little or no danger that it is involved in a private price-fixing arrangement."

Second, the Court considered the plaintiffs' contention that Eau Claire's tie-in was not pursuant to a "clearly articulated" state policy. Although a

53. 455 U.S. at 55.

54. See, e.g., H.R. REP. No. 965, supra note 26, at 2; Senate Committee Reviews Options for Legislation in Wake of Boulder, 46 Antitrust \& Trade Reg. Rep. (BNA) No. 1162, at 813-14 (Apr. 26, 1984); Local Government Antitrust Liability: The Boulder Decision: Hearings Before the Comm. on the Judiciary, 97th Cong., 2d Sess. (1982); Civiletti, The Fallout from Community Communications Co. v. City of Boulder: Prospects for a Legislative Solution, 32 CATH. U.L. REv. 379 (1983); Lopatka, supra note 3, at 23-25; Note, Community Communications Co. v. City of Boulder: The Emasculation of Municipal Immunity from Sherman Act Liability, 32 CATH. U.L. REV. 413 (1983). See generally Areeda, Antitrust Immunity for "State Action" After Lafayette, 95 HARv. L. REv. 435, 439 (1981).

55. See Local Government Antitrust Act of 1984, Pub. L. No. 98-544, 1984 U.S. Code CoNG. \& Admin. News (98 Stat.) 2750 (codified at 15 U.S.C. \$§ 1, 34-36 (Supp. II 1984)). The Act states that "In]o damages . . may be recovered under section $4,4 \mathrm{~A}$, or $4 \mathrm{C}$ of the Clayton Act ... from any local government, or official or employee thereof acting in an official capacity," 15 U.S.C. $\S 35$ (Supp. II 1984), and that no damages may be recovered from a private-party defendant "based on any official action directed by a local government, or official or employee thereof acting in an official capacity." 15 U.S.C. § 36 (Supp. II 1984).

The Act provides less immunity than if Congress had simply applied Parker equally to cities, in that it does not apply to injunctive actions, and in that for private-party defendants it appears to require municipal compulsion rather than mere approval. See 15 U.S.C. § 36 (Supp. II 1984) (referring to "official action directed by [a] local government") (emphasis added). The Act provides more protection than Parker, however, in that it contains no requirement of "clear articulation" or "active supervision" by the city.

56. 471 U.S. 34 (1985).

57. Id. at 47 (emphasis in original). For municipally regulated private parties to receive immunity, however, active supervision is still required. Id. at $46 \mathrm{n} .10$. Although Hallie states that active "state" supervision is required in such cases, $i d$., the word is best read in its generic sense as contemplating either state or municipal supervision. It would be extremely unwieldy, for example, for the Court to require active state-rather than merely municipal-supervision of rents charged by landlords under a municipal rent-control ordinance. 
state statute did grant cities authority to construct sewage systems, and to prescribe the districts to be served, plaintiffs argued that-as in Boulder-such authority did not necessarily contemplate that the city would operate those systems in an anticompetitive manner. ${ }^{58}$ Although Justice Powell began his response by insisting that such conduct was indeed a "foreseeable result" of empowering the city to refuse to serve unannexed areas, ${ }^{58}$ that contention was not self-evident. The Boulder Court would not have considered the mere grant of municipal authority to refuse to serve certain areas as contemplating the use of such a refusal to enforce an anticompetitive tie-in.

Nor was the Hallie Court willing to rely on this argument alone. Instead, it proceeded to distinguish Boulder on the ground that there the city possessed "only the most general" grant of local authority from the state, one which "simply did not address the regulation of cable television." to immunize any municipal regulation as long as the state has authorized the city to regulate that specific market sector-even if the state has not necessarily contemplated anticompetitive behavior. ${ }^{61}$ One possible message was that Boulder's intrusiveness would be limited to cases where the city's only authorization was in the form of a general home rule provision. The courts of appeals certainly appear to have read it that way: They have not rejected a single municipal action defense since the Court issued its opinion in Hallie. ${ }^{82}$

Whether the Court was now prepared to overrule Boulder, however, remained an open question. Hallie made that conceivable, since the dis-

\footnotetext{
58. See 471 U.S. at $41-43$.

59. Id. at 42 .

60. Id. at 43.
}

61. Indeed, the Court seemed to go out of its way not to rely solely on a much more express authorization of the very actions at issue in the case. In a footnote, the Court mentioned-but declined to regard as decisive - the Wisconsin Supreme Court's conclusion in a related state proceeding that the legislature had expected the city to undertake the challenged actions. See id. at 44 n.8.

62. See Coastal Neuro-Psychiatric Assocs. v. Onslow Memorial Hosp., 795 F.2d 340 (4th Cir. 1986); Mercy-Peninsula Ambulance, Inc., v. County of San Mateo, 791 F.2d 755 (9th Cir. 1986); Cine 42nd Street Theater Corp. v. Nederlander Org., 790 F.2d 1032 (2d Cir. 1986); Executive Town \& Country Servs. v. City of Atlanta, 789 F.2d 1523 (11th Cir. 1986); Falls Chase Special Taxing Dist. v. City of Tallahassee, 788 F.2d 711 (11th Gir. 1986); Racetrac Petroleum, Inc. v. Prince George's County, 786 F.2d 202 (4th Cir. 1986); Montauk-Caribbean Airways v. Hope, 784 F.2d 91 (2d Cir. 1986); LaSalle Nat'l Bank v. County of DuPage, 777 F.2d 377 (7th Cir. 1985), cert. denied, 106 S. Ct. 2892 (1986); Grason Elec. Co. v. Sacramento Mun. Util. Dist., 770 F.2d 833 (9th Cir. 1985), cert. denied, 106 S. Ct. 886 (1986); L \& H Sanitation, Inc. v. Lake City Sanitation, Inc., 769 F.2d 517 (8th Cir. 1985); Riverview Invs., Inc. v. Ottawa Community Improvement Corp., 769 F.2d 324 (6th Cir. 1985), modified, 774 F.2d 162 (6th Cir. 1985); Rural Elec. Co. v. Cheyenne Light, Fuel \& Power Co., 762 F.2d 847 (10th Cir. 1985); Independent Taxicab Drivers' Employees v. Greater Houston Transp. Co., 760 F.2d 607 (5th Cir. 1985), cert. denied, 106 S. Ct. 231 (1985); Preferred Communications, Inc. v. City of Los Angeles, 754 F.2d 1396 (9th Cir. 1985), affd, 106 S. Ct. 2034 (1986). 
tinction it implied between general and sector-specific grants of authority was without logical significance. After all, there had never been any suggestion that the City of Boulder was acting ultra vires in regulating cable television under its home rule powers. Boulder plainly had state authority to regulate; ${ }^{63}$ the doubt the Boulder Court expressed was whether the state had contemplated the specific anticompetitive acts in question. Hallie seemed to render such contemplation unnecessary.

Fisher v. City of Berkeley, ${ }^{84}$ an antitrust challenge to Berkeley's rent control ordinance, presented the Court with an opportunity to reconsider Boulder, since the ordinance was again largely based on authority derived from the home rule provisions of a state constitution. ${ }^{65}$ Once again, however, the Court declined to overrule Boulder. In striving to avoid the Boulder result, however, the Court went so far in the opposite direction that it risked toppling the entire state action edifice-particularly the Midcal test-that it had so laboriously constructed during the previous ten years.

In Fisher, the Court raised a threshold barrier for plaintiffs mounting antitrust attacks on the facial validity of state or local regulations. When presented with such a "pre-emption" attack, Justice Marshall wrote, courts need not even reach the question of state action immunity-nor Midcal's two-pronged test-unless the regulation were first found to conflict "irreconcilably" with the antitrust laws. In making that determination, he continued, the analysis is the same for both state and municipal regulation: To be in irreconcilable conflict, the regulation must constitute a per se violation of the Sherman Act. ${ }^{86}$

Justice Marshall rejected the contention that Berkeley's rent control ordinance did in fact constitute a per se violation of the prohibition on price fixing contained in section 1 of the Sherman Act. There can be no violation of section 1, he explained, in the absence of an agreement, and he refused to find such an agreement either among the landlords, or between the city and the landlords: "A restraint imposed unilaterally by government does not become concerted action within the meaning of the statute

63. See supra note 52 .

64. 106 S. Ct. 1045 (1986).

65. See Fisher v. City of Berkeley, 37 Cal. 3d 644, 655-56, 693 P.2d 261, 271-72, 209 Cal. Rptr. 682, 692-93 (1984) (citing CAL. ConST. art. XI, § 7), affd, $106 \mathrm{~S}$. Ct. 1045 (1986); see also $106 \mathrm{~S}$. Ct. at 1056-57 (Brennan, J., dissenting) (noting that California Supreme Court found authority for municipal rent control in home rule provisions of state constitution, and arguing that Boulder Court held similar provisions insufficient for immunity).

66. See $106 \mathrm{~S}$. Ct. at $1048-49,1051$. The Court first suggested this threshold test, with its requirement of a per se violation and its apparent limitation to facial challenges, in Rice v. Norman Williams Co., 458 U.S. 654, 661, 662 n.9 (1982); see also Boulder, 455 U.S. at 68-69 \& n.5 (Rehnquist, J., dissenting) (suggesting similar test). 
simply because it has a coercive effect upon parties who must obey the law." "'r7

As discussed below, Fisher is subject to serious criticism for misapprehending the difference between state action immunity and substantive violations of the Sherman Act. ${ }^{68}$ In addition, the precise scope of its threshold test remains unclear. At least for facial attacks on the validity of regulations, ${ }^{69}$ success appears to require proof of an "agreement"-a word whose meaning the opinion leaves in doubt, and which may collapse into nothing more than a restatement of Midcal's supervision requirement. ${ }^{70}$ For purposes of this Section, however, the important point is that Fisher represents yet a further retreat from judicial scrutiny of both local and state regulation. Fisher's requirement of an "agreement," applicable in challenges to both state and municipal action, imposes yet another barrier to an antitrust plaintiff's success. Notwithstanding the Justices' increasing economic sophistication and the nation's increasing disillusionment with economic regulation, ${ }^{71}$ the Court has made clear that it has no appetite for using antitrust law to discipline unreconstructed state or local regulators.

\section{The Compromise Explanation}

The revisionists are not blind to these empirical difficulties with the capture theory. To the contrary, they seek to explain the discrepancy between the Justices' assertedly growing concern for special-interest capture, and the actual case outcomes, by contending that the cases reflect an illconsidered compromise between Parker's deference to regulation and the capture theory's skepticism. It is this compromise that has allegedly led the Court to the two-pronged Midcal test. ${ }^{72}$

67. $106 \mathrm{~S}$. Ct. at 1049-50.

68. See infra text accompanying notes 99-135.

69. The Court appears to intend the preemption test announced in Fisher to govern only efforts to enjoin the enforcement of a regulation on its face, and not efforts to invalidate regulations for their effects as applied to individual cases. See $106 \mathrm{~S}$. Ct. at 1051 \& n.2. The Court made the same point in its first formulation of the "preemption" approach to state action questions. See Rice v. Norman Williams Co., 458 U.S. 654, 662 \& n.8 (1982) (noting that upholding facial validity of statute would still leave the "manner in which a [defendant] utilizes the ... statute . . subject to Sherman Act analysis.").

What this distinction would mean in particular cases, however, will not always be clear. See infra notes 116, 117. It was not even clear in Fisher. Justice Marshall noted, for example, that had the plaintiffs pressed a claim of attempted monopolization under $\S 2$ of the Sherman Act, rather than claiming a per se violation of $\S 1$, "the inquiry demanded by appellants' allegations [would have gone] beyond the scope of the facial challenge presented here." $106 \mathrm{~S}$. Ct. at $1051 \mathrm{n} .2$. Perhaps the inquiry would be different, but it is difficult to see how the result could be different. It is not possible to mount an antitrust challenge to a program like rent control on other than "facial" grounds, unless the federal court is to become a version of Berkeley's Rent Stabilization Board, with power to pass on the reasonableness of rents charged by individual landlords.

70. See infra text accompanying notes 99-135.

71. See supra text accompanying notes 22-27.

72. See Wiley, supra note 3 , at 729 . 
Professor Wiley regards the compromise as a bad one. He argues that, by emphasizing clear articulation and supervision, the Midcal test actually polices state delegations of authority rather than capture. But delegation, he says, is a poor proxy for capture, since special interests can capture state legislatures as well as regulatory bodies. According to Professor Wiley, it is the Court's mistaken decision to police delegation, when what it really wanted to do was police capture, that has led to the inconsistency between the Court's underlying motivations and the cases' actual results. ${ }^{73}$

Judge Easterbrook makes a similar point. He contends that the Court has chosen to require active supervision because it believes that to be the best method of limiting the gains of special interests. This approach is short-sighted, he argues, because while the supervision requirement cannot effectively prevent capture, it may well force states to adopt the form of regulation least favorable to allocative efficiency. And this he regards as particularly ironic, in light of what he believes is the post-Parker Court's assumption that state regulatory laws represent anticompetitive dispensations to politically powerful groups. ${ }^{74}$

There is, however, a different explanation for why the cases do not accord with the capture theory, namely, that concern over regulatory capture is not what has motivated the Court. An active supervision requirement is an ironic expressicn of capture concerns because the Court has not been motivated by such concerns, and delegation is a poor proxy for capture because the Court never intended it to play such a role. Instead, the restriction on delegation was intended to reconcile the Court's respect for the political process in the states with its respect for the national political process. When viewed in this light the Midcal test serves its purposes tolerably well, and the case law can be explained without recourse to the revisionists' somewhat Procrustean methods.

\section{B. State Action Immunity as Respect for the Political Process}

\section{The State Action Cases}

Parker v. Brown was much less a case about judicial faith in economic regulation than it was a case about judicial respect for the political process. Parker was indeed a child of its times, but the most salient element of that historical context was the Court's recent rejection ${ }^{78}$ of the Lochnerera doctrine of substantive due process, under which federal courts struck down economic regulations they viewed as unreasonably interfering with

73. See id. at $731-33,739$.

74. See Easterbrook, Antitrust and Federalism, supra note 3, at 27-32.

75. See Olsen v. Nebraska, 313 U.S. 236 (1941); West Coast Hotel Co. v. Parrish, 300 U.S. 379 (1937); Nebbia v. New York, 291 U.S. 502 (1934). 
the liberty of contract. ${ }^{78}$ Having only just determined not to use the Constitution in that manner, the Court was not about to resurrect Lochner in the garb of the Sherman Act. ${ }^{77}$

It is this theme, rather than a concern for policing capture, that is sounded in a number of subsequent state action opinions. ${ }^{78}$ It is a theme also reflected in the Court's repeated declaration that the anticompetitive effect of a statute cannot be sufficient for its invalidation, else "the States' power to engage in economic regulation would be effectively destroyed."79 And it is a concern whose validity has been repeatedly brought home to the Court by the tendency of plaintiffs, even in the post-Lochner era, to couple antitrust attacks on state regulation with appeals to the due process clause. ${ }^{80}$ When the Court finds state action immunity in the same cases in which it rejects substantive due process attacks, ${ }^{81}$ it cannot help but recognize that the ghost of Lochner lurks behind both doors.

In a federal scheme of government, however, respect for the political process alone is insufficient to decide those cases in which the political processes at the state and national levels give conflicting signals. The Parker Court understood this dilemma well. On the one hand, the Court did not believe Congress had intended the Sherman Act to "nullify" a state's regulation of its own economy; ${ }^{82}$ on the other hand, it was equally sure that Congress would not have permitted a state to nullify the Sherman Act itself by "authorizing" private parties "to violate" the Act "or by declaring that their action is lawful."

The post-Parker cases constitute the Court's effort to thread this

76. See Lochner v. New York, 198 U.S. 45 (1905); G. GunTHER, Cases AND MATERIALS ON Constitutional. Law 441-62 (11th ed. 1985); L. Tribe, American Constitutional Law 434-42 (1978).

77. See Verkuil, State Action, Due Process and Antitrust: Reflections on Parker v. Brown, 75 Col.uM. L. REv. 328, 331-34 (1975). Indeed, the California statute at issue in Parker was based on a federal statute, the Agricultural Adjustment Act of 1933, that the Court had at one time declared largely unconstitutional, United States v. Butler, 297 U.S. 1 (1936), but had recently upheld in reenacted form as the Agricultural Marketing Agreement Act of 1937, United States v. Rock Royal Coop., 307 U.S. 533 (1939). See Wiley, supra note 3, at 719 n.18.

78. See Rice v. Norman Williams Co., 458 U.S. 654, 664 (1982) (rejecting parallel due process challenge); New Motor Vehicle Bd. v. Orrin W. Fox Co., 439 U.S. 96, 106-07 (1978) (same); Exxon Corp. v. Governor of Md., 437 U.S. 117, 124 (1978) (same); see also Community Communications Co. v. City of Boulder, 455 U.S. 40, 67-68 (1982) (Rehnquist, J., dissenting) (waming of dangers of reviving Lochner-type scrutiny through Sherman Act); City of Lafayette v. Louisiana Power \& Light Co., 435 U.S. 389, 421 (1978) (Burger, C.J., concurring) (holding in Parker understandable as reaction against substantive due process); Cantor v. Detroit Edison Co., 428 U.S. 579, 640 (1976) (Stewart, J., dissenting) (accusing Court of applying substantive due process under Sherman Act guise).

79. Exxon Corp., 437 U.S. at 133; see Rice, 458 U.S. at 659; New Motor Vehicle Bd., 439 U.S. at 110-11.

80. See Rice, 458 U.S. at 664; New Motor Vehicle Bd., 439 U.S. at 106-07; Exxon, 437 U.S. at 124; Joseph E. Seagram \& Sons v. Hostetter, 384 U.S. 35, $45-47$ (1966).

81. See cases cited supra note 80 .

82. 317 U.S. at 351 .

83. Id. 
needle-an effort to protect true state regulation, even if anticompetitive, but to bar mere state "authorization" of private anticompetitive conduct. Judged by this standard, the clear articulation/active supervision test is not a dismal compromise between faith in regulation and fear of capture. Instead, it is a relatively sensible compromise between the judiciary's obligation to respect the results of the democratic process at the state level and its obligation to respect that same process at the national level.

As part of that compromise, the "clear articulation" requirement ensures that antitrust law will not be set aside unless the state does in fact intend to displace competition, i.e., the challenged scheme does not simply represent unsanctioned private conduct. ${ }^{84}$ The supervision requirement ensures that even where there is state authorization, such authorization constitutes more than mere permission to violate the Sherman Act. A state may displace the Act, but in doing so it must replace it with a scheme of state regulation. ${ }^{85}$

Professor Wiley is correct, then, in describing the articulation/supervision test as an effort to control delegation. ${ }^{86}$ The test seeks to immunize action taken by the state qua state, but to bar delegation to private parties of the power to restrain competition. ${ }^{87}$ As the Court made clear in Midcal, its purpose is to prevent a state from thwarting the national policy in favor of competition by casting "a gauzy cloak of state involvement over what is essentially a private price-fixing arrangement."

84. In Goldfarb, for example, the Court rejected the Virginia Bar's assertion of state authorization for its minimum fee schedules, where examination revealed that the state supreme court had actually "directed lawyers not "to be controlled' by fee schedules." Goldfarb v. Virginia State Bar, 421 U.S. 773, 789 (1975) (citation omitted); see also Southern Motor Carriers Rate Conf. v. United States, 471 U.S. 48, 61 (1985) (explaining Goldfarb). In Bates, however, the Court upheld a prohibition on lawyer advertising when it determined that the restraint was ordered by the state court itself. See Bates v. State Bar, 433 U.S. 350, 359-62 (1977); see also Hoover v. Ronwin, 466 U.S. 568, 570-73 (1984) (explaining Bates). See generally 1 P. AREedA \& D. TuRNER, supra note 15, II 214; Areeda, supra note 54, at 437.

85. Hence, the Court rejected the state action defense in Midcal because the state had essentially authorized private resale price maintenance without making any effort to replace antitrust prohibitions with state supervision. See California Retail Liquor Dealers Ass'n v. Midcal Aluminum, Inc., 445 U.S. 97, 103, 105-06 (1980); see also Town of Hallie v. City of Eau Claire, 471 U. 34, 39-40 (1985) (explaining Midcal). It upheld the defense in Parker itself, however, where California officials supervised the raisin marketing program established by state-authorized grower committees. See Parker v. Brown, 317 U.S. 341, 346-47, 352 (1943); see also Midcal, 445 U.S. at 104 (explaining Parker). See generally 1 P. AREedA \& D. TuRner, supra note 15, 11 213; Areeda, supra note 54, at 436-37.

86. See Wiley, supra note 3 , at $733,739$.

87. See Southern Motor Carriers Rate Conf. v. United States, 471 U.S. 48,57 (1985); Town of Hallie v. City of Eau Claire, 471 U.S. 34, 38, 46-47 (1985); Community Communications Co. v. City of Boulder, 455 U.S. 40, 70 (1982) (Rehnquist, J., dissenting); Goldfarb v. Virginia State Bar, 421 U.S. 773,792 (1975).

88. 445 U.S. at 106. 


\section{The Municipal Action Cases}

The problem with the Court's opinions in its first two municipal action cases, Lafayette and Boulder, was that they sought to police all delegations of state legislative power, not simply delegations to private parties. Based on a technical, ${ }^{89}$ and debatable, ${ }^{80}$ conception of federalism, the Court declined to treat cities as equivalent to states for purposes of the Sherman Act. Consequently, the Court effectively treated federal antitrust law as a species of state administrative law, determining which intrastate allocations of political power should be given effect and which should not. ${ }^{91}$ The flaw in this approach is that the Sherman Act contains no warrant for policing cities' pursuit of their parochial-but still public-interests; that is a matter for state law and state courts. On this point, both Professor Wiley and Judge Easterbrook concur. ${ }^{92}$

The two most recent municipal action cases reflect the Court's recognition of -although not yet a willingness to renounce-the problem inherent in Boulder, and a new determination to limit itself to policing delegations to private parties. In Hallie, the Court declared that "the Sherman Act was intended to prohibit private restraints on trade"; $; 3$ that unlike a private party, "[w]e may presume . . . [a] municipality acts in the public interest"; $;$ and that "[w] $[$ here the actor is a municipality, there is little or no danger that it is involved in a private price-fixing agreement." ${ }^{\text {"9s }} \mathrm{AC}$ cordingly, it held state supervision unnecessary for municipal immunity. ${ }^{\circ 6}$

89. The Boulder opinion was based on the "federalism principle that we are a Nation of States, a principle that makes no accommodation for sovereign subdivisions of States." Community Communications Co. v. City of Boulder, 455 U.S. 40, 50 (1982) (emphasis in original); see also City of Lafayette v. Louisiana Power \& Light Co., 435 U.S. 389, 412 (1978) (plurality opinion) ("Cities are not themselves sovereign; they do not receive all the federal deference of the States that create them.").

90. As the dissenters in Boulder and Lafayette noted, see Boulder, 455 U.S. at 69-70 (Rehnquist, J., dissenting); Lafayette, 435 U.S. at 430 \& n.7 (Stewart, J., dissenting), the Court has treated cities as equivalent to states in numerous other contexts in which federalism concerns are no less pressing. See, e.g., National League of Cities v. Usery, 426 U.S. 833 (1976) (Tenth Amendment), overruled on other grounds, Garcia v. San Antonio Metro. Transit Auth., 469 U.S. 528 (1985); City of Burbank v. Lockheed Air Terminal, Inc., 411 U.S. 624 (1973) (supremacy clause); Avery v. Midland County, 390 U.S. 474 (1968) (Fourteenth Amendment). But see Edelman v. Jordan, 415 U.S. 651,667 n.12 (1974) (political subdivisions not protected by Eleventh Amendment). Indeed, the Parker Court itself noted that that case involved "no question of the state or its municipality becoming a participant in a private agreement." Parker v. Brown, 317 U.S. 341, 351 (1943) (emphasis added).

91. See Areeda, supra note 54, at 453-55; see also Boulder, 455 U.S. at 71 (Rehnquist, J., dissenting) (criticizing Court's use of Sherman Act to regulate relation between states and their political subdivisions); Lafayette, 435 U.S. at 434-38 (Stewart, J., dissenting) (criticizing Court's interference with state's ability to delegate power to its municipalities).

92. See Easterbrook, Antitrust and Federalism, supra note 3, at 36-38; Wiley, supra note 3, at $735,766$.

93. Town of Hallie v. City of Eau Claire, 471 U.S. 34, 38 (1985) (emphasis in original) (citing Parker, 317 U.S. at 351).

94. Id. at 45 .

95. Id. at 47 (emphasis in original).

96. Id. The Court also cited Justice Stewart's dissent in Lafayette, warning that imposing too strict a "clear articulation" requirement would have "detrimental side effects upon municipalities" 
Similarly, in Fisher, the Court announced it would treat cities and states alike for purposes of its threshold preemption analysis, ${ }^{97}$ without suggesting any reason to treat cities differently for "preemption" than for "immunity"-a point the author of Boulder and Lafayette understandably viewed as effectively discarding those cases. ${ }^{98}$

The Court's unwillingness to overrule Boulder, however, led to its effort in Fisher to achieve the same result by focusing on the absence of "agreement" in Berkeley's rent control ordinance. That focus, however, confuses the question of whether a substantive violation of the antitrust laws has occurred with the question of whether, notwithstanding any violation, the restraint at issue constitutes state action.

Where a restraint is challenged as violating section 1 of the Sherman Act, the presence of an agreement is, of course, essential to liability. ${ }^{99}$ The Fisher Court correctly concluded that the rent control ordinance involved no such agreement among landlords; indeed, the landlords had brought the suit challenging the ordinance and were opposed to its provisions. ${ }^{300}$ And the Court was equally correct in finding no agreement between the city and the landlords (or the tenants, for that matter). As the Court explained, "[t]he ordinary relationship between the government and those who must obey its regulatory commands whether they wish to or not is not enough to establish a conspiracy." ${ }^{101}$ Indeed, unless a city itself participates in a private conspiracy ${ }^{102}$ - a circumstance that is perhaps best limited to cases of outright bribery or corruption ${ }^{103}$ - the existence of a true agreement involving a city will almost always be lacking in cases of municipal regulation. To hold otherwise would be to deem the very social contract that binds citizens together a "conspiracy" in restraint of trade. ${ }^{104}$

But the existence of a substantive violation of the Sherman Act was not the issue in Fisher. The plaintiff landlords were not seeking to hold anyone liable under the Act; they would have been the only possible co-

local autonomy and authority to govern themselves." 471 U.S. at 44 (citing Lafayette, 435 U.S. at 434-35).

97. See Fisher v. City of Berkeley, 106 S. Ct. 1045, 1048 (1986); supra text accompanying notes 64-71.

98. See 106 S. Ct. at 1053, 1056 (Brennan, J., dissenting); see also infra text accompanying notes 127-35 (noting similarity between preemption and immunity analysis).

99. Section 1 of the Sherman Act requires a "contract, combination . . . or conspiracy" to establish a violation. 15 U.S.C. $\$ 1$ (1982); see Monsanto Co. v. Spray-Rite Serv. Corp., 465 U.S. 752,761 (1984).

100. See 106 S. Ct. at 1047, 1049-50.

101. Id. at 1050 .

102. See id. at 1051; Parker v. Brown, 317 U.S. 341, 351-52 (1943) ("IW]e have no question of the state or its municipality becoming a participant in a private agreement or combination . . ..."). 103. See P. AREEDA, ANTrTruST LAW II 203.3c (Supp. 1982); Areeda, supra note 54, at 451-52. 104. See Brief for Appellees at 19, Fisher v. City of Berkeley, 106 S. Ct. 1045 (1986) (No. 841538). 
conspirators. ${ }^{105}$ To the contrary, they sought not treble damages, the classic remedy for a Sherman Act violation, but rather an injunction against the rent control ordinance's enforcement, ${ }^{106}$ the classic remedy in preemption cases. ${ }^{107}$ The plaintiffs' contention was that the ordinance, on its face, conflicted with section 1 of the Sherman Act and was therefore invalid under, and preempted by, the Constitution's supremacy clause. ${ }^{108}$

The test for preemption, ${ }^{108}$ Justice Marshall said, was whether the ordinance was "irreconcilably" in conflict with the antitrust laws. ${ }^{110}$ Such an irreconcilable conflict could not result "simply because the state scheme may have an anticompetitive effect." "11x As the Court explained in Exxon Corp. v. Governor of Maryland, "if an adverse effect on competition were, in and of itself, enough to render a state statute invalid, the States' power to engage in economic regulation would be effectively destroyed."112 Justice Marshall suggested that an irreconcilable conflict could result if city officials corruptly participated in a conspiracy with landlords ${ }^{113}$ (which could also constitute a substantive violation by the city), or if the ordinance were nothing more than a "gauzy cloak" for a private price-fixing conspiracy among the landlords ${ }^{114}$ (which would preempt the ordinance but should not render the city itself liable as a violator of the Sherman Act ${ }^{115}$ ).

But the Court had never before held that cases involving such conspiracies were the only ones in which preemption could result. Indeed, such a

105. The landlords did not suggest that the tenants were involved in any alleged conspiracy. See Fisher v. City of Berkeley, 37 Cal. 3d 644, 667 \& n.17, 693 P.2d 261, 280 \& n.17, 209 Cal. Rptr. 682, 701 \& n.17 (1984) (noting plaintiffs' assertion that ordinance was facially invalid because it created vertical combinations between rent board and individual landlords and horizontal combination among landlords), affd, 106 S. Ct. 1045 (1986).

106. See Fisher, 37 Cal. 3d at 653, 693 P.2d at 270, 209 Cal. Rptr. at 69l.

107. See, e.g., Jones v. Rath Packing Co., 430 U.S. 519, 523-24 (1977); Community Communications Co. v. City of Boulder, 455 U.S. 40, 64-65 (1982) (Rehnquist, J., dissenting) (describing effect of preemption as simply rendering statute unenforceable).

108. See Fisher, 37 Cal. 3d at 656-57, 660, 693 P.2d at 272-73, 275, 209 Cal. Rptr. at 693-94, 696.

109. As noted below, the test for "preemption" and that for state action "immunity" ultimately converge. See infra text accompanying notes 127-35.

110. Fisher, 106 S. Ct. at 1048 (quoting Rice v. Norman Williams Co., 458 U.S. 654, 659 (1982)). In Silkwood v. Kerr-McGee Corp., 464 U.S. 233, 248 (1984), the Court held that state law is preempted "to the extent it actually conflicts with federal law, that is, when it is impossible to comply with both" or "where the state law stands as an obstacle to the accomplishment of the full purposes and objectives of Congress."

111. 106 S. Gt. at 1048 (quoting Rice, 458 U.S. at 659).

112. 437 U.S. 117,133 (1978).

113. See $106 \mathrm{~S}$. C. at 1051 .

114. Id.

115. See Boulder, 455 U.S. at 64-65, 68 n.4 (Rehnquist, J., dissenting). Once the ordinance is preempted, private parties could no longer rely on it for a municipal action defense. Whether liability could be assessed for the period prior to the ordinance's preemption, however, is a question the Court has not yet decided. See Cantor v. Detroit Edison Co., 428 U.S. 579, 600 (1976) (plurality opinion); id. at 614 n.6 (Blackmun, J., concurring); 1 P. AREEDA \& D. TuRNER, supra note 15, $11217 \mathrm{~b}$. 
result could hardly be justified since section 2 of the Sherman Act, unlike section 1, proscribes wholly unilateral conduct. ${ }^{116}$ Moreover, even as to challenges involving section 1, the Court had never before made the presence of an "agreement" a prerequisite to preemption. ${ }^{117}$

In Midcal, for example, a California statute prohibited wholesalers from selling a producer's wine at a price other than that set in a schedule filed by the producer. ${ }^{118}$ There was no question of any agreement among wholesalers, nor was there any agreement between the producer and the wholesaler. Indeed, the suit was brought by a wholesaler who had refused to abide by the scheduled prices. ${ }^{119}$ As the Court held with respect to the landlord-plaintiffs in Fisher, a restraint complied with-if at all-under threat of state coercion does not constitute a "meeting of the minds."120 Nonetheless, the Midcal Court invalidated the statute, finding that it amounted to unsupervised resale price maintenance. ${ }^{121}$

To much the same effect is Schwegmann Bros. v. Calvert Distillers Corp. ${ }^{122}$ At issue in Schwegmann was a Louisiana state law requiring a retailer who had not signed a resale price maintenance agreement to follow the prices set in contracts between his distributor and other retailers who had signed. Since at the time the Miller-Tydings Act ${ }^{23}$ exempted the

116. See 15 U.S.C. $\$ 2$ (1982) (declaring monopolization and attempts to monopolize unlawful); 3 P. AREfDa \& D. TURNer, supra note 15 , I 820 . Justice Marshall anticipated this point by suggesting that $\S 2$ attacks, unlike per se attacks under $\S 1$, were not truly preemptive because "the inquiry demanded . . . goes beyond the scope of [a] facial challenge." $106 \mathrm{~S}$. Ct. at 1051 n.2; $c f$. supra note 69 (suggesting Court has limited "preemption" analysis to facial challenges). Even if that were true in a case like Fisher, it certainly is not always true. No detailed rule of reason analysis would be required, for example, to disclose the anticompetitive effects of an ordinance establishing a municipally-owned monopoly in a previously competitive market. Nor would there be much to distinguish a facial challenge to such an ordinance from one seeking to overturn the ordinance "as applied." Accordingly, if such an ordinance is to survive antitrust challenge, it must do so because it satisfies the Midcal criteria-not because it does not involve "agreement." See infra text accompanying notes 127-35.

117. Boulder itself involved a plaintiff's effort, using $\S 1$ of the Sherman Act, to enjoin an ordinance that temporarily prohibited the expansion of its cable business into new areas of the city. See 455 U.S. at 46-47; see also id. at 62 (Rehnquist, J., dissenting) (describing issue as "on[e] of preemption rather than exemption"). The district court had found insufficient evidence to establish a conspiracy between the city and the plaintiffs competitor, see id. at $47 \mathrm{n} .9$, the only agreement even hypothetically conceivable in the case. Nonetheless, the Supreme court found the city's ordinance to lie outside the state action defense because it was not undertaken pursuant to a clearly articulated state policy. See id. at 54-56.

118. California Retail Liquor Dealers Ass'n v. Midcal Aluminum, Inc., 445 U.S. 97, 99-100 (1980); see Rice v. Norman Williams Co., 458 U.S. 654, 659 (1982) (describing challenge to Midcal statute as one involving preemption).

119. 445 U.S. at 100 .

120. See Fisher, 106 S. Ct. at 1050 (citing American Tobacco Co. v. United States, 328 U.S. 781, $810(1946))$.

121. 445 U.S. at $103,105$.

122. 341 U.S. 384 (1951).

123. District of Columbia Revenue Act of 1937 , ch. 690,50 Stat. 673,693 , repealed by Consumer Goods Pricing Act of 1975, Pub. L. No. 94-145, 89 Stat. 801. The Act was an amendment to $\S 1$ of the Sherman Act, and provided that "nothing herein contained shall render illegal, contracts or agreements prescribing minimum prices for the resale [of specified commodities] when contracts or agree- 
signed agreements from Sherman Act challenge, the only question in the case was the validity of the statutory provision affecting those who had not agreed. ${ }^{124}$ Despite the absence-by definition-of any challengeable agreement, the Court held the statute to violate "the spirit of the proviso which forbids 'horizontal' price fixing," and refused to permit its enforcement against non-signers. ${ }^{125}$

With a minor adjustment, Fisher itself can be made to look like Midcal and Schwegmann. In Fisher, the Court distinguished Berkeley's ordinance, which it declined to strike, from a cartel among landlords, which it would have struck, by arguing that only the latter involved an agreement. ${ }^{128}$ But now suppose that Berkeley had simply permitted a single landlord-or a single tenant-to choose a price unilaterally, which the city then required all others to pay. The scheme would plainly approximate the cartel result; indeed it would be more anticompetitive because it would avoid the risk of price cheating inherent in a cartel. Yet, this time the Court would not have the luxury of distinguishing the scheme from that in Fisher by noting the presence of an agreement. Nonetheless, Midcal and Schwegmann would still compel preemption.

What makes Midcal, Schwegmann, and the modified Fisher hypothetical irreconcilable with the Sherman Act is not the presence of agreement. Rather, it is the state or local government's effort to delegate to private parties the power to restrain competition, such private restraints being the particular evil Congress intended the Sherman Act to prevent. ${ }^{127}$ But this, of course, is precisely the issue at the heart of the state action immunity cases. ${ }^{128}$ Indeed, as noted above, it is the function of the two-pronged Midcal test to determine whether just such a delegation has occurred. ${ }^{\mathbf{1 2 9}}$

The statutes in Schwegmann and Midcal failed that test because in those cases the states did not supervise private restraints; the prices the states enforced were chosen by the producers or distributors alone. ${ }^{130} \mathrm{On}$ the other hand, what saved rent control in Fisher was not the absence of abstract agreement, but rather the fact that the ordinance "place[d] complete control over maximum rent levels exclusively in the hands of the

ments of that description are lawful as applied to intrastate transactions [under local law]." 50 Stat. 673, 693. The Louisiana statute included both signer provisions covered by the Miller-Tydings Act, and the non-signer provisions at issue in Schwegmann. See 341 U.S. at 386-87.

124. See 341 U.S. at $387-88,395$.

125. Id. at 389 (emphasis added).

126. See Fisher, 106 S. Ct. at 1049.

127. See Town of Hallie v. City of Eau Claire, 471 U.S. 34, 38 (1985); cases cited supra notes 87-88; see also Parker v. Brown, 317 U.S. 341, 352 (1943) ("[T]he Sherman Act . . . must be taken to be a prohibition of individual and not state action.").

128. See supra text accompanying notes $75-88$.

129. See supra text accompanying notes 84-88.

130. See Midcal, 445 U.S. at 105; Schwegmann, 341 U.S. at 386-87; 1 P. AREEDA \& D. TURNER, supra note 15 , II $209,213 \mathrm{~b}$. 
[city's] Rent Stabilization Board."131 Moreover, the fact that the ordinance was enacted pursuant to Berkeley's home rule powers-and hence without the specific state authorization that Boulder had required-was largely ignored. In short, whether the Court describes the state action doctrine as a question of exemption, ${ }^{132}$ immunity, ${ }^{133}$ or preemption ${ }^{134}$-and whether the case involves a state or a municipality-it is the two-pronged Midcal test that now effectively determines whether the regulation at issue is subject to Sherman Act attack.

There are signs that the Fisher Court understood the way in which its preemption analysis collapses into the Midcal test. Justice Marshall suggested, for example, that there may be certain "hybrid" restraints that, although imposed by government, could not be called wholly "unilateral." ${ }^{135} \mathrm{He}$ listed Midcal and Schwegmann as illustrations, and implied that municipal ordinances using similar restraints would be preempted. As this Section has shown, however, the problem in those cases was not the presence of a "hybrid" agreement, but rather the state's failure to supervise the private restraints it had authorized. The Court could thus make the municipal action cases far more coherent by simply making Midcal directly applicable to cities-expressly overruling Boulder-rather than continuing its scholastic debate over the meaning of the word "agreement."

\section{Summary}

Both the state and municipal action cases reflect the Court's determination to prevent states from using Parker immunity to cede to private parties the power to restrain the market. That determination does represent a compromise, but not-as the revisionists suggest-a compromise between faith in regulation and suspicion of regulatory capture. Rather, it represents an effort to reconcile state and federal interests, in the context of an underlying respect for the results of the political process at both levels. It is this effort that explains why the Court never adopted a wholly hands-

131. See $106 \mathrm{~S}$. Ct. at 1051 . Similarly, what saved state regulation in prior cases was the presence of state authorization and supervision, rather than the absence of agreement. See, e.g., New Motor Vehicle Bd. v. Orrin W. Fox Co., 439 U.S. 96, 109-10 (1978); Bates v. State Bar, 433 U.S. 350, 362 (1977).

132. See New Motor Vehicle Bd., 439 U.S. at 109; City of Lafayette v. Louisiana Power \& Light Co., 435 U.S. 389, 393 n.8 (1978); see also Goldfarb v. Virginia State Bar, 421 U.S. 773, 788 (1975) ("this so-called state-action exemption").

133. See Southern Motor Carriers Rate Conf. v. United States, 471 U.S. 48, 65-66 (1985); Hoover v. Ronwin, 466 U.S. 558, 560 (1984); Midcal, 445 U.S. at 103; 1 P. AREEDA \& D. TuRNER, supra note 15, II 211.

134. See Rice v. Norman Williams Co., 458 U.S. 654, 662 n.9 (1982); Community Communications Co. v. City of Boulder, 455 U.S. 40, 60 (1982) (Rehnquist, J., dissenting); Handler, Antitrust-1978, 78 Cor.um. L. REv. 1363, 1378-82 (1978).

135. $106 \mathrm{~S}$. Ct. at 1050 . 
on or wholly hands-off approach to state regulation, but instead struggled with a series of different criteria for measuring the depth of state involvement, finally coming to rest at the articulation/supervision test. True state action, whether undertaken by the state or its municipality, is to be protected out of respect for the political process at the state or municipal level; effectively private action is to be policed out of respect for Congress' mandate in the Sherman Act.

\section{The Dangers of an Efficiency/Capture Test}

In addition to describing where they think the state action doctrine has been, many revisionists have proposals for where it ought to go. Not only has concern over the inefficient results of regulatory capture motivated the Court in the past, they argue, but it should continue to do so in the future-only more expressly.

As Professor Wiley has set forth the most detailed proposal for a revision of the state action doctrine, his suggestion will be the principal focus here. Wiley proposes a new, essentially two-pronged test to replace the one used in Midcal. Under this test, the Sherman Act would preempt state or local regulation that: (1) restrains market rivalry without responding directly to a substantial market inefficiency, and (2) originates from the decisive political efforts of producers who stand to profit from the restraint. ${ }^{136}$ Other writers have advanced tests incorporating one or more of these or similar factors. ${ }^{137}$ The following two Sections consider the dangers independently posed by each of Professor Wiley's two prongs although, as noted below, he would require satisfaction of both prongs to trigger preemption.

\section{A. The Economic Efficiency Criterion}

Were a state action test simply to condemn any statute that restrained competition, most if not all state and local market regulation would expire. ${ }^{138}$ Recognizing this, ${ }^{130}$ Professor Wiley has included a market defect proviso in the first prong of his proposed test: A state may escape preemption by showing that the challenged regulation directly addresses a substantial market inefficiency, a showing that the courts should examine

136. See Wiley, supra note 3, at 743. As described in his article, Professor Wiley's test is actually four-pronged. The first prong set forth in the text above condenses two elements Wiley lists separately. Professor Wiley's fourth prong would protect any regulation covered by an independent federal antitrust exemption. Since in theory that point is unobjectionable, it is not considered in this Article.

137. See infra notes $141,160$.

138. See Exxon Corp. v. Governor of Md., 437 U.S. 117, 133 (1978) ("II]f an adverse effect on competition were, in and of itself, enough to render a state statute invalid, the States' power to engage in economic regulation would be effectively destroyed.").

139. See Wiley, supra note 3 , at 745 . 
with an "intermediate level" of scrutiny. ${ }^{140}$ Professor Cirace, Messrs. Werden and Balmer, and several other authors have proposed related tests. ${ }^{141}$

The parallels between this efficiency test and the test employed in Lochner are sobering. ${ }^{142}$ Exercising an intermediate level of scrutiny, a revisionist antitrust court would consider the appropriateness of the state purpose involved (Does it address a serious market defect?); ${ }^{143}$ determine whether the regulation is an effective means of achieving that purpose (Are there less restrictive alternatives?); ${ }^{144}$ and then judge the regulation's overall reasonableness in that light (Do the costs outweigh the benefits?). ${ }^{145}$ But these are virtually the identical inquiries made by the Supreme Court during the Lochner era, ${ }^{\mathbf{1 4 8}}$ and it was the exercise of just such discretionary power by federal judges that the post-Lochner cases sought to preclude. As the Court proclaimed in Ferguson v. Skrupa, the

140. See id. at $743,748,762-64$.

141. See Cirace, supra note 3 , at 486 (proposing preemption unless, inter alia, "substantial market inadequacies are inherent . . . [and] the competitive displacement is no greater than the scope of the market problems at which it is aimed"); Werden \& Balmer, supra note 3, at 61 (barring preemption where state's purpose was "to correct a failure of the market" and where state did not go "further than was necessary to achieve" its purpose); see also Cantor v. Detroit Edison Co., 428 U.S. 579, 610-13 (1976) (Blackmun, J., concurring) (proposing "rule of reason" test requiring that where ending competition is state's objective, there must be evidence "that such competition is in some way ineffective"); Donnem, supra note 3, at 967 (proposing exemption only where the state has a "legitimate local reason for limiting competition" and "there is no less restrictive alternative"); Posner, supra note 3, at 707-14 (proposing that economic regulation be protected only if it is "public utility" regulation, but that health and safety regulation be protected if it satisfies "rule of reason").

Professor Slater's proposal involves more outright "balancing" than most of those cited in this footnote, requiring the state to "demonstrate that it had a valid reason behind its regulation and that the interest furthered by the regulation was of greater significance than preserving competition." See Slater, supra note 3, at 104; see also Kennedy, supra note 3, at 73 (also proposing balancing test). If anything, Professor Slater's approach is even more Lochnerian than Professor Wiley's. See infra text accompanying notes $142-48$.

142. See Community Communications Co. v. City of Boulder, 455 U.S. 40, 67 (1982) (Rehnquist, J., dissenting); Verkuil, supra note 77, at 334. Judge Easterbrook recognizes similar parallels and would oust only those anticompetitive state regulations that impose overcharges on citizens of other states. See Easterbrook, Antitrust and Federalism, supra note 3, at 24-25, 45-50. Professor Cirace also recognizes the similarity; he, however, argues that a substantive due process standard should be applied in state action cases. See Cirace, supra note 3 , at 484 .

143. Wiley, supra note 3, at 748, 764; see Cantor, 428 U.S. at 613 (Blackmun, J., concurring); Cirace, supra note 3 , at 486,515; Donnem, supra note 3, at 967; Posner, supra note 3 , at 707 ; Werden \& Balmer, supra note 3, at 61; cf. Slater, supra note 3, at 104 (requiring state to have "a valid reason" behind its regulation).

144. Wiley, supra note 3, at 763; see Cirace, supra note 3, at 486, 498, 515; Donnem, supra note 3, at 967; Kennedy, supra note 3, at 73; Posner, supra note 3, at 707, 714; Slater, supra note 3, at 105; Werden \& Balmer, supra note 3 , at 61.

145. Wiley, supra note 3, at 763-64; see Cantor, 428 U.S. at 610 (Blackmun, J., concurring); Kennedy, supra note 3, at 73; Posner, supra note 3, at 714; Slater, supra note 3, at 104; Werden \& Balmer, supra note 3, at 61-62.

146. See Lochner v. New York, 198 U.S. 45, 57 (1905) (holding that the state's "end itself must be appropriate and legitimate," that the "act must have a more direct relation, as a means to an end," and that there "is no reasonable ground for interfering with the liberty of person or the right of free contract, by determining the hours of labor, in the occupation of a baker"); L. TRIBE, supra note 76, at $436-42$. 
federal judiciary does not sit as a "superlegislature to weigh the wisdom of legislation" " passed by elected officials. ${ }^{147}$

Moreover, it is not only its methodology that makes the efficiency test dangerously like Lochner; its effects are likely to be comparable as well. If antitrust concepts developed for private restraints are applied to state action, regulations as disparate as zoning and occupational licensing, exclusive franchises and rent control, minimum wages and minimum hours could all be overturned. ${ }^{148}$ This should hardly be surprising, as most such regulations were not intended to correct market inefficiencies, but to serve other social values. Whether the trade-offs such regulations represent are intelligent ones is, of course, open to debate; but whether federal courts should make that determination is a debate the Court thought it had ended in the 1930's.

It is no coincidence that in many of the Supreme Court cases involving antitrust attacks on state regulation, plaintiffs have also advanced "due process" challenges that make virtually the identical substantive arguments. ${ }^{149}$ Until now, the Court has been able to dispose of the due process challenges by citing cases like Ferguson $v$. Skrupa, ${ }^{150}$ while disposing of the antitrust challenges by citing cases like Parker $v$. Brown..$^{151}$ If the efficiency test is adopted, however, the same regulations that survive constitutional scrutiny are likely to fall under the antitrust knife.

Professor Wiley defends his proposal on two principal grounds. First, he argues that placing judges in a policymaking role is not inconsistent with Congress' intent in passing the Sherman Act. By using sweeping language, yet providing little guidance in terms of legislative history, Congress, he asserts, intended to grant courts common law power to make substantive policy. ${ }^{162}$

147. 372 U.S. 726, 728-31 (1963) (quoting Day-Brite Lighting, Inc. v. Missouri, 342 U.S. 421 , 423 (1952)); see Lincoln Fed. Labor Union v. Northwestern Iron \& Metal Co., 335 U.S. 525, 535-37 (1949); Community Communications Co. v. City of Boulder, 455 U.S. 40, 67-68 (1982) (Rehnquist, J., dissenting).

148. See Boulder, 455 U.S. at 66 (Rehnquist, J., dissenting); City of Lafayette v. Louisiana Power \& Light Co., 435 U.S. 389, 439 (1978) (Stewart, J., dissenting). Professor Wiley agrees that the efficiency test, if applied alone and without his additional capture criterion discussed infra text accompanying notes 158-92, "would logically lead courts to use the Sherman Act[] . . to question any state or local policy that affects resource allocation by altering the rewards to economic activities." Wiley, supra note 3, at 765. He notes that such "traditional state and local laws" as "market prohibitions on prostitution, marijuana, and baby-selling; restrictions on gun, firework, and drug sales; and limitations such as rent, usury, and condominium conversion controls" could all become actionable. Id. Another revisionist suggests an additional list of "possibly anticompetitive state laws," including "Sunday closing and other blue laws, . . . state taxation schemes which discriminate among competitors, building and construction regulations which favor some competitors over others, zoning ordinances ... [and] occupational licensing." Donnem, supra note 3, at 951.

149. See cases cited supra note 80.

150. 372 U.S. 726 (1963).

151. 317 U.S. 341 (1943).

152. See Wiley, supra note 3 , at 776-77. 
But divining a congressional intention to permit common law development of the rules governing private restraints is one thing; ${ }^{153}$ extending that to permit judicial overruling of the policy choices of state and local governments is quite another. It is true that there is little in the Sherman Act's legislative history that expressly addresses the state action question one way or the other. ${ }^{154} \mathrm{~A}$ recognition of that congressional silence, however, simply shifts the operative question to who should bear the burden of proof. And, in light of the drastic implications of applying antitrust concepts to state action, the Parker Court's allocation seems about right: "In a dual system of government in which . . . the states are sovereign, ... an unexpressed purpose to nullify a state's control over its officers and agents is not lightly to be attributed to Congress."155 In other words, if Congress had intended the antitrust laws to be used to overturn hundreds of statutes in virtually every state, one might expect some congressman to have at least mentioned the possibility.

Professor Wiley's second defense is more fundamental. His test is not Lochner revisited, he argues, because it is not a constitution he is expounding. While Lochner's interpretation of the due process clause could not be overturned without a constitutional amendment (or a change in the Court's views or membership), Congress can overturn a misinterpretation of the Sherman Act-if that is what the efficiency test turns out to be-any time it likes. ${ }^{106}$

It is true, of course, that the Sherman Act is not a constitution, repeated references to "charter[s] of freedom" and "Magna Carta[s]" notwithstanding. ${ }^{167}$ Its language does have constitutional breadth, however, and if interpreted as the revisionists would like, it would have a preemptive power exceeding even that of the genuine document. Moreover, although it is

153. See, e.g., United States v. United States Gypsum Co., 438 U.S. 422, 438-39 \& n.14 (1978); National Soc'y of Professional Eng'rs v. United States, 435 U.S. 679, 688 (1978); P. AREedA, ANTITRUST ANAt.ysis II 144, at 48-50 (3d ed. 1981). But see Texas Indus. v. Radcliff Materials, 451 U.S. 630, 642-47 (1981) (Congress granted courts far less discretion to fashion Sherman Act remedies than to define violations).

154. See Slater, supra note 3, at 83. But see Southern Motor Carriers Rate Conf. v. United States, 471 U.S. 48, 56 n.19 (1985) (quoting H.R. REP. No. 1707, 51st Cong., 1st Sess. 1 (1890) for proposition that "[t]here are . . . some statements in the legislative history that affirmatively express a desire not "to invade the legislative authority of the several States." "); Cantor v. Detroit Edison Co., 428 U.S. 579, 632-37 (1976) (Stewart, J., dissenting) (arguing that Sherman Act Congress understood its commerce clause power as being too narrow to preempt state regulation); Parker v. Brown, 317 U.S. 341, 351 (1943) ("The sponsor of the bill ... . declared that it prevented only "business combinations." ").

155. 317 U.S. at 351; see Note, The State Action Exemption and Antitrust Enforcement Under the Federal Trade Commission Act, 89 Harv. L. Rev. 715, 721 (1976).

156. See Wiley, supra note 3 , at 779 .

157. See United States v. Topco Assocs., 405 U.S. 596, 610 (1972) ("Antitrust laws in general, and the Sherman Act in particular, are the Magna Carta of free enterprise."); Appalachian Coals, Inc. v. United States, 288 U.S. 344, 359-60 (1933) ("As a charter of freedom, the Act has a generality and adaptability comparable to that found to be desirable in constitutional provisions."). 
also true that Sherman Act interpretations are subject to congressional reversal, that escape hatch is available in all questions of statutory interpretation. Its existence does not relieve courts of the obligation to decide the matter in the first instance, thereby determining who will bear the burden of legislative change. The adoption of an efficiency test would sanction massive judicial intrusion into the policies of public officials and state legislatures. That the proposed test is not immutable may distinguish it from Lochner (though Lochner ultimately was not immutable either); it does little, however, to reduce its sting.

\section{B. The Capture Criterion}

The above debate about the appropriateness of an efficiency criterion notwithstanding, Professor Wiley recognizes that a preemption test composed of that criterion alone would jeopardize a breathtaking array of state and local policies. ${ }^{158}$ To limit the imperial breadth of the test, he therefore adds a second prong: State regulation should be preempted only if it is both inefficient and a result of the decisive political efforts of the producers who stand to profit from it, i.e., if it is the product of "producer capture." A plaintiff may establish this criterion by adducing direct evidence of decisive producer lobbying, or by showing indirectly that the facial characteristics of the regulation suggest capture and requiring the state to rebut the inference. ${ }^{139}$ Other revisionists have made comparable suggestions. ${ }^{160}$ This Section considers the constitutional problems raised both by the general concept of a capture test and by Professor Wiley's further proposal to limit preemption to instances of "producer"-as opposed to "consumer"-capture.

\section{Capture}

The problem with the capture criterion is that it imposes a penalty on rights that are at the core of the First Amendment: the right to debate

158. See Wiley, supra note 3 , at 765; supra note 148.

159. See Wiley, supra note 3 , at 743 .

160. See Cirace, supra note 3 , at $485,486,498,514,515$ (proposing that private parties be permitted to benefit from competitive displacements only if chosen in manner consistent with due process and ethical conduct); Slater, supre note 3, at 105 (favoring balancing test that would "prevent the enforcement of unnecessarily protective legislation which usually benefits only a special interest group rather than the public as a whole"); Werden \& Balmer, supra note 3, at 61 (proposing that state statutes be preempted where animated by "illegitimate, anticompetitive purpose[s]"); $c f$. Easterbrook, Foreword, supre note 2, at 15-19, 54 (arguing that courts should narrowly construe statutes passed to benefit special interests, and suggesting that one way to determine whether a statute is special-interest legislation is to ask, "Who lobbied for the legislation?"); id. at 18-19 ("A]nticompetitive bargains embedded in state legislation will become targets for challenge under the antitrust laws; the deference due toward a statute that corrects 'market failures' is not due toward a statute that creates them."). 
public issues, to petition the government, and to seek to influence the outcome of the political process. ${ }^{161}$ Professor Wiley's reply is that the penalty imposed is in fact quite light. Defendants are not penalized for lobbying per se; they are penalized only if their proposal is enacted, and then the only penalty is invalidation. ${ }^{162}$ Yet such a scheme makes the lobbyists' protected political activity the only thing that renders the regulation illegal; but for their involvement, the program they seek would pass judicial inspection. As such, the capture test is likely to chill protected activity far more than would a monetary penalty imposed directly on lobbying itself, for it applies what for the lobbyist must be the ultimate sanction. ${ }^{163}$ After all, why lobby for a bill which, once it passes the legislature, must fail in the courts because of your lobbying?

Indeed, deterring interest group lobbying is the whole idea behind the capture test. The hope is that by deterring such lobbying the Sherman Act's efficiency interest will be advanced. ${ }^{104}$ Accordingly, the capture test must rely on a more basic defense: Even if the test penalizes lobbying, it only penalizes those who lobby for selfish, anticompetitive laws. Producers remain free to lobby as much as they want to cure genuine market inefficiencies. ${ }^{168}$ But it is precisely this kind of effort to select the subjects about which a person may speak, and the persons who may speak about a subject, that treads most heavily on First Amendment freedoms. ${ }^{166}$ Making the speaker's self-interest the selection criterion only increases the damage.

The leading case supporting this critique of the capture criterion is Eastern Railroad Presidents Conference v. Noerr Motor Freight, in which the Court held that a violation of the Sherman Act could not be

161. See Brown v. Hartlage, 456 U.S. 45, 52-53 (1982); First Nat'l Bank of Boston v. Bellotti, 435 U.S. 765, 776-77 (1978); Buckley v. Valeo, 424 U.S. 1, 14-15 (1976).

Professor Wiley correctly points out that one can read Cantor v. Detroit Edison Co., 429 U.S. 579, 594 (1976), which denied state action immunity to an electric utility's free lightbulb program despite agency approval, as counting against immunity the utility's request for such approval. See Wiley, supra note 3, at 780 \& n.308. But Cantor was inconsistent with both Parker and Noerr in that regard, see Parker v. Brown, 317 U.S. 341, 346-47 (1943) (noting raisin producers' role in petitioning for regulatory program); infra note 167 (quoting Noerr), and the Court effectively abandoned that element of Cantor in Bates v. State Bar, 433 U.S. 350, 360-63 (1977). See 1 P. AREEDA \& D. TURNER, supra note 15, T 215b; Handler, supra note 134, at 1385.

162. See Wiley, supra note 3 , at 780-81. Professor Wiley also argues that the restriction on lobbying is narrow. Only lobbying of state and local legislatures is limited; producers remain free to lobby Congress to achieve their interests. Id. The availability of such a federal override, however, has never been held to displace the constitutional right to petition one's state legislature. See, e.g., Eastern R.R. Presidents Conf. v. Noerr Motor Freight, 365 U.S. 127 (1961) (discussed infra text accompanying notes $167-70$ ).

163. See Brown v. Hartlage, 456 U.S. 45, 61 (1982) (holding unconstitutional state election law that penalized candidate's protected political activity by invalidating his election); infra note 167 (quoting Noerr).

164. See Wiley, supra note 3 , at 772-73.

165. Id. at 780 .

166. See First Nat'l Bank of Boston v. Bellotti, 435 U.S. 765, 785 (1978). 
predicated upon an attempt to influence the passage of legislation. ${ }^{167}$ Relying on both statutory interpretation and First Amendment considerations, ${ }^{188}$ the Court held that the legality of the defendant railroads' lobbying campaign "was not at all affected by any anticompetitive purpose it may have had." 168 As Justice Black explained:

The right of the people to inform their representatives in government of their desires with respect to the passage or enforcement of laws cannot properly be made to depend upon their intent in doing so. . . . A construction of the Sherman Act that would disqualify people from taking a public position on matters in which they are financially interested would ... deprive the ... people of their right to petition in the very instances in which that right may be of the most importance to them. ${ }^{170}$

Subsequent cases have made much the same point by emphasizing that the right to endeavor to influence public opinion includes the right to do so out of self-interested, and even blatantly anticompetitive, motives. ${ }^{171}$ In-

167. 365 U.S. 127, 135 (1961); see also California Motor Transp. Co. v. Trucking Unltd., 404 U.S. 508, 510-11 (1972) (extending Noerr to efforts to, influence administrative agencies); United Mine Workers v. Pennington, 381 U.S. 657, 669-72 (1965) (extending Noerr to efforts to inlluence public officials).

In Noerr, the asserted violation was the act of lobbying itself rather than, as here, the legislative result of such lobbying. As discussed above, however, invalidating the result inhibits the exercise of First Amendment rights even more than does penalizing lobbying directly. See supra text accompanying note 163; see also Noerr, 365 U.S. at $137 \mathrm{n.17}$ ("In Parker v. Brown . . . we rejected the contention that the program's validity under the Sherman Act was affected by the nature of the political support necessary for its implementation-a contention not unlike that rejected here.") (emphasis added).

168. See 365 U.S. at 137-40. Subsequent cases have emphasized Noerr's First Amendment rationale. See Bellotti, 435 U.S. at 792 n.31; City of Lafayette v. Louisiana Power \& Light Co., 435 U.S. 389, 399 \& n.17 (1978); California Motor Transp., 404 U.S. at 509-11.

169. 365 U.S. at 140; see id. at 138 (dismissing as irrelevant allegation that defendants' "sole purpose in seeking to influence the passage and enforcement of laws was to destroy... competitors").

170. 365 U.S. at 139. The Noerr doctrine does include a "sham" exception, but the exception does not apply to the kind of genuine efforts to influence legislation that would be invalidated under the capture test. See 365 U.S. at 144; Handler \& De Sevo, The Noerr Doctrine and Its Sham Exception, 6 CARDOzo L. REv. 1, 7-14, 54-55 (1984). In particular, the exception almost never applies to situations in which lobbyists succeed in convincing the government to adopt their proposals, and thereby demonstrate that their lobbying efforts were not merely a frivolous cover for activity not truly intended to influence the government. See 1 P. Arefda \& D. Turner, supra note 15, If 203c. Yet such lobbying successes are the only situations to which the capture test would apply. See supra text accompanying note 162 .

171. For example, in California Motor Transp. Co. v. Trucking Unltd., 404 U.S. 508 (1972), the Court said:

We conclude that it would be destructive of rights of association and of petition to hold that groups with common interests may not, without violating the antitrust laws, use the channels and procedures of state and federal agencies and courts to advocate their causes and points of view respecting resolution of their business and economic interests vis-ä-vis their competitors. Id. at 510-11; see United Mine Workers v. Pennington, 381 U.S. 657, 669-70 (1965) (ruling that Sherman Act does not bar firms from seeking Labor Department regulations intended to drive smaller rivals out of market); 1 P. ARkFDA \& D. TuRNer, supra note 15, İ 201; $f f$. Consolidated Edison Co. 
deed, the Court has suggested that such interest group politics is at the heart of the Madisonian democratic tradition. "We have never insisted that the franchise be exercised without taint of individual benefit," Justice Brennan wrote in Brown v. Hartlage. "[O]ur tradition of political pluralism is partly predicated on the expectation that voters will pursue their individual good through the political process, and that the summation of these individual pursuits will further the collective welfare."172 There may be much that is offensive about the reality of interest-group politics, and much reason to hope that individuals will transcend their private interests and seek instead the public good. ${ }^{173}$ But the Court has never sanctioned the restriction of political speech as a method of ensuring that they do so.

Given the penalty the capture test imposes on core First Amendment interests, it must undergo the most exacting scrutiny if it is to pass constitutional muster. ${ }^{174}$ That is a scrutiny the capture test cannot survive. To begin with, although the governmental interest in preserving a competitive market is surely a legitimate one, Noerr makes clear that it is not constitutionally compelling. The message of Noerr is that Congress did not intend, and that the Constitution will not permit, the federal interest in an efficient marketplace to outweigh the right to participate in the political process. ${ }^{175}$ And Noerr and Hartlage make equally clear that a subordinate interest in deterring political appeals either from or to selfinterest is similarly uncompelling. ${ }^{176}$

Nor is the capture test a narrowly tailored ${ }^{277}$ means for achieving the interest in a competitive economy. First, the test is underinclusive. If a market restraint is inefficient, why is it any more acceptable if it is the product of ignorance rather than avarice?178

v. Public Serv. Comm'n, 447 U.S. 530 (1980) (holding that state may not bar utility from discussing its support for nuclear power); Bellotti, 435 U.S. at 776 (holding that state may not restrict bank's campaign against tax referendum); supra note 169 (quoting Noerr).

172. 456 U.S. 45,56 \& n.7 (1982) (citing THE Federalist No. 10 (J. Madison)); see Noerr, 365 U.S. at 139.

173. See Hartlage, 456 U.S. at 56 n.7; THE FEDERALIST No. 51 (J. Madison); Sunstein, Interest Groups in American Public Law, 38 Sran. L. Rev. 29 (1985); Tribe, Constitutional Calculus: Equal Justice or Economic Efficiency?, 98 HARv. L. REv. 592, 616 n.146 (1985).

174. See Hartlage, 456 U.S. at 53-54; Consolidated Edison, 447 U.S. at 540; Bellotti, 435 U.S. at 786.

175. See Noerr, 365 U.S. at 139, 143-44 (holding that Sherman Act does not reach lobbying campaign even if campaign has both anticompetitive purpose and anticompetitive effect); see also NAACP v. Claiborne Hardware Co., 458 U.S. 886, 913-14 (1982) (interpreting Noerr).

176. See Hartlage, 456 U.S. at 56 ("The fact that some voters may find their self-interest reflected in a candidate's commitment does not place that commitment beyond the reach of the First Amendment."); id. at 60 ("The State's fear that voters might make an ill-advised choice does not provide the State with a compelling justification for limiting speech."); supra text accompanying notes 169-72 (quoting Noerr and Hartlage); see also supra note 171 (citing post-Noerr cases).

177. See Pacific Gas \& Elec. Co. v. Public Utils. Comm'n, 106 S. Ct. 903, 913-14 (1986); Hartlage, 456 U.S. at 54; Consolidated Edison, 447 U.S. at 540; Bellotti, 435 U.S. at 786, 793, 794.

178. The answer Professor Wiley suggests is that where a legislature has been captured, "the 
But the capture test is overinclusive as well, largely because the concept of "capture" is virtually undefinable. American legislation, at all governmental levels, is filled with subsidies both blatant and concealed. From tax deductions, to small business loans, to farm programs, to minority setasides, American legislation rewards political victors-both those in the majority and those who create successful minority coalitions. The antitrust laws themselves are hardly immune, as made manifest by special exceptions for the soft drink and insurance industries. ${ }^{179}$ In a society dominated by interest-group politics, "capture" is often just a pejorative for political success, and a committed interest group theorist is likely to have little trouble viewing virtually any political result as the product of capture by special interests. ${ }^{180}$ Given the difficulty both in determining individual legislators' motives, and in assessing the significance of conflicting motives, a capture test is likely to do little else than put enormous discretionary power into the hands of an unelected judiciary. ${ }^{181}$

\section{Producer Capture}

Professor Wiley recognizes the potentially indiscriminate nature of a general capture test. To remedy that deficiency, he proposes one more refinement: The courts should subject to antitrust scrutiny only those regulatory programs that have been captured by "producers"; regulations arising from "consumer" capture should remain immune. ${ }^{182}$

The producer proviso, however, retains the constitutional flaws of the

state . . . interest in self-governance is at its minimum," Wiley, supra note 3 , at 769 , and "state political decisionmaking. . . deserv[es] less deference," id. at 764. This, however, is nothing more than a restatement of the argument that the results of interest-group politics are unworthy of judicial respect, a position the Court rejected in Noerr and Hartlage. See supra text accompanying notes $164-73$.

179. See Soft Drink Interbrand Competition Act, 15 U.S.C. $\$ 3501$ (1982); McCarran-Ferguson Act, 15 U.S.C. \$ 1012(b) (1982) (insurance).

180. See S. BRtYYR, supra note 21 , at 388 n.38; Tribe, supra note 173 , at 616 . In light of the criminal penalties imposed by the antitrust laws, this definitional problem may also render the capture test void for vagueness. See Buckley v. Valeo, 424 U.S. 1, 40-44 (1975).

181. There is a sense in which Professor Wiley's preemption test is more deferential to state regulation than the Midcal test. For example, in situations where capture is absent, his test would immunize state-sanctioned anticompetitive conduct even if the conduct were not supervised and clearly articulated by the state. For the reasons noted in the text, however, this possibility is more theoretical than real since regulations not characterizable as "captured" will be rare. Moreover, were such a situation actually to occur, what the Wiley test would add in deference to state law would be more than offset by the lack of deference it would accord the federal antitrust laws. For example, were a state's citizens to pass a referendum permitting private price-fixing within the state, the Wiley test would immunize such a law from antitrust attack as long as the voters appeared motivated not by capture but by public interest (e.g., a genuine concern for the employees of a declining domestic industry). Such a result, however, would effectively permit the state to nullify the Sherman Act within its boundaries, a result difficult to square with notions of either congressional intent or federalism. Indeed, it was to avoid precisely this difficulty that the Court turned to the compromise embodied in Midcal. See supra text accompanying notes 82-88.

182. See Wiley, supra note 3 , at 742-43, 768-69. 
general capture test. The governmental interests at issue are the same, and remain uncompelling when compared to the restrictions on speech. The test itself remains underinclusive. To parallel a point made earlier, if the preemptive federal interest is allocative efficiency, why should an inefficient restraint stand simply because it has the benefit of "consumer" support? Although Professor Wiley regards Fisher v. City of Berkeley as a case deserving immunity because it involves "consumer" capture, ${ }^{183}$ few economists would regard Berkeley's rent control ordinance as any less inefficient because it was the product of tenant rather than landlord pressures. ${ }^{184}$

Nor is the problem of definition, and so of overinclusiveness, materially improved by adding a producer caveat. Do condominium conversion limitations stem from renter-and therefore presumably "consumer"-a ctivism, or from lobbying by existing condominium owners who wish to limit the supply of competing housing? Are regulations that tie the sale of new cars to the purchase of airbags generated by "producer" pressure because the insurance industry seeks them, or by consumer pressure because Ralph Nader's Center for Auto Safety files an amicus brief? ${ }^{185}$.

The irony, moreover, is that if the definitional problem could be solved, the producer caveat would only exacerbate the capture test's First Amendment problems. Classification of a political actor as a "producer" does not reduce its First Amendment rights any more than would its classification as a "corporation." As the Court held in First National Bank of Boston v. Bellotti, and recently confirmed in Pacific Gas $\mathcal{E}$ Electric Co. v. Public Utilities Commission, the identity of the speaker does not determine whether its speech is either worthy or protected. ${ }^{186}$

What such classification does do, however, is eliminate any pretense of content neutrality, any claim that the governmental interest is unrelated to the suppression of free expression, and so any warrant for reducing the level of judicial scrutiny. ${ }^{187}$ To the contrary, preferring one speaker over another is the central purpose of the producer capture test. The premise is that special interest groups like producers wield undue influence because

183. Id. at 768 .

184. See E. Mansfikid, supra note 32, at 73-74; P. SAmuelson \& W. Nordhaus, Economics 393-94 (12th ed. 1985).

185. See State Farm Mut. Auto. Ins. Co. v. Department of Transp., 680 F.2d 206, 207-08 (D.C. Cir. 1982), vacated sub nom. Motor Vehicle Mfrs. Ass'n of United States v. State Farm Mut. Auto. Ins. Co., 463 U.S. 29 (1983).

186. See Pacific Gas \& Elec. Co. v. Public Utils. Comm'n, 106 S. Ct. 903, 907, 912 (1986); First Nat'l Bank of Boston v. Bellotti, 435 U.S. 765, 777, 784 (1978); see also Consolidated Edison Co. v. Public Serv. Comm'n, 447 U.S. 530, 533 (1980); Eastern R.R. Presidents Conf. v. Noerr Motor Frcight, 365 U.S. 127, 137 n.17 (1961).

187. See Pacific Gas \& Elec., 106 S. Ct. at 910-11; Consolidated Edison, 447 U.S. at 536-37, 540 n.9; Buckley v. Valeo, 424 U.S. 1, 16-18 (1976); United States v. O'Brien, 391 U.S. 367, 381-82 (1968). 
of their greater ability to organize effectively for political action, and that, accordingly, some steps to redress the balance are required. ${ }^{188}$ Precisely the same argument was made-and rejected-during the Court's consideration of campaign expenditure limitations in Buckley v. Valeo:

It is argued . . . that the ancillary governmental interest in equalizing the relative ability of individuals and groups to influence the outcome of elections serves to justify the limitation[s] . . . But the concept that government may restrict the speech of some elements of our society in order to enhance the relative voice of others is wholly foreign to the First Amendment . . . ${ }^{\mathbf{1 8 9}}$

The jurisprudence of the First Amendment reflects the fundamental choice of a democracy to entrust to its citizens the responsibility for evaluating public policy proposals. ${ }^{190}$ The people may choose to judge a program by its friends, or they may overlook the taint of association altogether; they may make wise choices, or they may make foolish ones. Government, however, may not "fix" the result by restricting access to the political process. It is the capture test's contemplation of just such a fix that would render it unconstitutional even if it had Congress' express blessing. ${ }^{191}$ Surely recognition of that fact must stifle altogether any impulse to imply such congressional intent from a statute that makes not the slightest mention of it. ${ }^{192}$

\section{CONCLUSION}

When litigants first began a spate of antitrust challenges to state regulatory programs, they presented the Court with a difficult dilemma: how to respect the political process in the states without frustrating Congress' purpose in enacting the Sherman Act. The resolution the Court reached, sometimes precarious and often difficult to apply in individual cases, was to focus on preventing the delegation to private $\mathrm{p}_{i}^{\prime} \mathrm{r}^{\prime} \mathrm{ies}$ of the power to restrain competition. As long as a state retained effective control over the regulation of its economy, the federal judiciary would honor that state's

188. See Wiley, supra note 3 , at 724-25, 732; see also Cirace, suprit note 3 , at 483 n.19. See generally Easterbrook, Foreword, supra note 2, at 15-16 (noting organizational advantages of producers in seeking regulatory legislation).

189. 424 U.S at 48-49; see Pacific Gas Eo Elec., 106 S. Ct. at 914; Belloiti, 435 U.S. at 785, 789-92.

190. See Brown v. Hartlage, 456 U.S. 45, 60 (1982); Bellotti, 435 U.S. at 791-92; Thornhill v. Alabama, 310 U.S. 88, 95 (1940); Whitney v. California, 274 U.S. 35-, 377 (1927) (Brandeis, J., concurring); Abrams v. United States, 250 U.S. 616, 630 (1919) (Holmes, J., dissenting); Meiklejohn, The First Amendment Is an Absolute, 1961 Sup. CT. REv. 245, $26 \dot{3}$.

191. See cases cited supra note 189.

192. See Eastern R.R. Presidents Conf. v. Noerr Motor Freight, 365 U.S. 127, 137-38, 139 (1961). 
political decision to restrain market forces. When the state relinquished control to private parties, however, the national political decision to bar such private regulation would prevail.

At bottom, the flaw in the proposals to revise the state action doctrine is that they take two useful analytic tools-microeconomic theory and capture theory-and apply them as normative concepts in an area in which they are inapposite. There is much to be said-and debated ${ }^{183}$-about the merits of using economic efficiency criteria to derive antitrust rules for private commercial conduct, or to assist policymakers in weighing the costs and benefits of public programs. But it is a considerable leap to move from such analytic applications to the notion that federal courts should use the state action doctrine to preempt state regulations that impose inefficient restraints on market competition.

Similarly, there is much to be said-and debated ${ }^{184}$-about the uses of capture theory in understanding legislation and regulation, and even in crafting administrative law doctrine. The theory may enhance the democratic process by informing legislators, regulators, and voters of the true genesis of programs put forward in the guise of the public interest. In administrative law, it may lead to closer judicial scrutiny of captured agencies to ensure that they truly heed the legislative will. ${ }^{195}$

But using capture theory as a criterion for applying the state action doctrine is another matter altogether. In that context, it is used neither as a tool for understanding politics, nor as an instrument for ensuring agency fidelity to the results of the political process. To the contrary, when used as the touchstone for preempting state law, capture theory becomes a weapon for overturning those results. And that is a role the courts should not permit the antitrust laws to play.

193. Compare R. Posner, Anttrrust Law: An Economic Perspective (1976) with Pitofsky, The Political Content of Antitrust, 127 U. PA. L. REv. 1051 (1979).

194. See, e.g., M. Derthick \& P. Quirk, The Politics of Deregulation 252-58 (1985) (arguing that recent experience with deregulation suggests that American political system is capable of overcoming interest-group pressures).

195. Cf. Garland, supra note 36, at 553-61 (noting role of "hard look" review in ensuring agency fidelity to legislative purpose); Sunstein, supra note 173, at 63, 65 (arguing that rigorous scrutiny seeks to ensure that agencies implement public values and are not subverted by private groups). 
